\title{
Metodika pro hodnocení environmentální výchovy pro předškolní a mladší školní věk
}

\section{Jan Činčera}

Envigogika 8 (5) - Metodiky/Methodologies

Publikováno/published 31. 12. 2013

DOI: http://dx.doi.org/10.14712/18023061.413

\begin{abstract}
Abstrakt
Metodika předkládá souhrn nástrojů pro evaluaci programů environmentální výchovy určených pro žáky předškolního a mladšího školního věku. Vymezuje relevantní proměnné environmentální výchovy a diskutuje strategie pro jejich kvantitativní i kvalitativní evaluaci. Uvádí príklady z domácích i zahraničních evaluačních výzkumů.
\end{abstract}

\section{Klíčová slova}

evaluace, kvantitativní, kvalitativní, programy

\begin{abstract}
The methodology provides a comprehensive overview of instruments aimed for evaluation of environmental education programmes for pre-school and K-5 elementary school pupils. It defines relevant variables for environmental education and discusses strategies for their quantitative and qualitative evaluation. Examples of evaluation research from Czech and abroad are provided.
\end{abstract}

\section{Key words}

evaluation, qualitative, quantitative, programme 


\section{METODIKA PRO HODNOCENÍ PROGRAMŮ ENVIRONMENTÁLNÍ VÝCHOVY PRO PŘEDŠKOLNÍ A MLADŠÍ ŠKOLNÍ VĚK}

Jan Činčera, Masarykova univerzita Brno, Katedra environmentálních studií, 2013

\section{OBSAH}

Úvod

Specifika evaluací programů pro děti předškolního a mladšího školního věku 4

Vztah k přírodě. 6

Vymezení rámcových cílů . .6

Potřeba kontaktu s prrírodou 7

Schopnost prímého kontaktu s prírodou . 10

Citlivost k přírodě

Reflexe různých pohledů na přírodu 16

Vztah k místu 21

Ekologické děje a zákonitosti 25

Environmentální problémy a konflikty. 32

Připravenost jednat ve prospěch životního prostředí. 36

Závěr.. 41

Použitá literatura 44

Př́lohy 48

Príloha č. $12-\mathrm{MEV}$ 48 
Předkládaná metodika je jedním z výstupů projektu TAČR „Hodnocení efektivity nástrojů environmentálního vzdělávání, výchovy a osvěty (EVVO)“, řešícího výzkumnou potřebu Ministerstva životního prostředí. Je určená pro formativní i sumativní evaluace programů environmentální výchovy určené pro věkovou skupinu předškolního a mladšího školního věku. Předpokládá, že jejími uživateli budou zejména:

- Interní evaluátoři ze středisek ekologické výchovy;

- Subjekty poskytující finanční podporu programů EVVO;

- Externí evaluátoři z neziskových organizací, vysokých škol či jiných subjektů;

- Studenti a vyučující na vysokých školách zaměřující se na výzkum v oblasti environmentální výchovy.

Efektivní využití metodiky vyžaduje určité vstupní kompetence na straně uživatele. Těmi jsou především:

- Základní orientace v problematice EVVO, zejména v oblasti porozumění cílů EVVO a znalost běžných typů nabízených programů EVVO;

- Znalost základních principů analýzy a evaluace programu EVVO (Činčera, 2010);

- Znalosti a dovednosti voblasti metodologie výzkumu v sociálních vědách, zejména schopnost zpracovávat jednoduchá statistická data (např. testy statistické významnosti) a získávat a analyzovat kvalitativní data (např. pomocí kódovacích technik).

Metodika není vhodná pro:

- Programy neodpovídající uvedené cílové skupině;

- Programy zaměřené primárně na jiné výchovně-vzdělávací oblasti, než je EVVO;

- Služby nebo jiné typy produktů, které nemají charakter programu, tj. postrádají jasně definované cíle a aktivity, které mají vést $\mathrm{k}$ jejich naplnění.

Evaluace programů environmentální výchovy je jedním ze základních předpokladů jejich efektivity. Hodnocení může prokázat, že předpoklady, vkládané do vztahu mezi cíli a aktivitami programu fungují podle očekávání a program je žádoucí dále nabízet. Stejně tak ale mohou prokázat, že $v$ důsledku chyb $v$ teorii či implementaci program nefunguje a je zapotřebí jej změnit. Bez zavedení systému pravidelných evaluací programů proto není systém environmentální výchovy v žádné zemi dlouhodobě udržitelný.

Diskuse o evaluaci programů environmentální výchovy probíhá v České Republice od roku 2006 (Činčera, 2006). Od té doby byly publikovány evaluace několika významnějších programů, např. programu GLOBE (Činčera, 2011; Činčera, Fleková \& Kopecký, 2011; Činčera, Kováčiková, Mašková, Medal \& Medalová, 2012; Činčera, 2012a,b,c,d). V roce 2010 pak byla publikována Metodika evaluace programů environmentální výchovy (Činčera, 2010).

Spolu sdiskusí o evaluaci došlo v návaznosti na zahraniční vývoj i k redefinici domácího pojetí cílů environmentální výchovy. Ke změně v pojetí environmentální výchovy $v$ kurikulárních dokumentech vyzvaly $\checkmark$ roce 2011 tzv. Doporučené očekávané výstupy (Pastorová a kol., 2011a,b). Na ně pak navázal dokument Cíle a indikátory EVVO zpracované v roce 2012 v rámci pracovní skupiny při Ministerstvu životního prostředí ČR (Broukalová a kol., 2012).

Snahou autorů posledně zmíněného dokumentu bylo mimo jiné provázat domácí pojetí environmentální výchovy se zahraničním a naznačit, jakým způsobem by bylo možné ověřovat efektivitu programů usilujících o naplnění vymezených cílových oblastí.

Předkládaná metodika na tento dokument bezprostředně navazuje. Jejím cílem je poskytnout základní přehled strategií pro evaluaci cílu vymezených v Cílech a indikátorech EVVO, se zaměřením na programy pro předškolní 
děti a žáky mladšího školního věku. Na studii navážou další dvě metodiky, zaměřené na evaluaci programů pro starší žáky a posléze pro dospělé účastníky.

Metodika je rozčleněna podle jednotlivých „oblastí cílů“ vymezených v Cílech a indikátorech EVVO (Broukalová a kol., 2012). V první části jsou vždy prezentovány rámcové cíle, které pro danou oblast dokument vymezuje. Ve druhé části jsou k rámcovým cílům přiřazeny a definovány příklady proměnných, které s cíli korespondují. Při jejich vymezení vycházel autor ze snahy respektovat výsledky dohodnuté v rámci pracovní skupiny pro vymezení Cílů a indikátorů EVVO a představující tedy široký konsensus domácí odborné komunity. Současně usiloval o propojení se zahraničním diskursem a zavedení proměnných, které jsou v mezinárodní odborné literatuře diskutovány a měřeny. Je třeba zmínit, že ani v zahraniční literatuře nejsou některé proměnné jednoznačně definovány a $v$ jejich uplatňování někdy panuje značná volnost. Velikou práci na převodu zahraniční terminologie odvedl u nás především Krajhanzl (2010), jehož disertační práce představuje jeden z prvních pokusů o vytvoření domácího odborného diskursu v oblasti ekopsychologie. Studie se v některých př́padech drží Krajhanzlem (2010) vytvořených českých ekvivalentů (např. překlady pojmů environmental awareness, environmental concern), v některých př́padech je ale diskutuje, prípadně přichází s jinými definicemi, které považuje za vhodnější pro evaluační praxi.

Po vymezení proměnných následují komentované př́klady různých kvantitativních i kvalitativních nástrojů, které byly použity, př́padně jsou použitelné pro jejich vyhodnocování. Metodika obsahuje řadu hotových nástrojů (dotazníků, testů), které je možné převzít pro vlastní evaluační praxi. Metodika současně předpokládá, že její uživatelé ovládají základy evaluační metodologie (Činčera, 2010), respektive alespoň základní orientaci v metodologii kvantitativního a kvalitativního výzkumu.

Současně je třeba upozornit na to, že ne vždy může být vhodný postup „převzít“ nástroj pro evaluaci konkrétního programu. Realizátoři či evaluátoři programů by měli v první řadě posoudit validitu nástroje pro daný program. To předpokládá, že program se ve vymezení svých obecných výchovně-vzdělávacích cílů (goals) hlásí k některé z proměnných, které jsou v textu definovány. Pokud tomu tak není, hrozí, že použitý nástroj bude měřit jinou proměnnou, než jaká je programem ovlivňována. Evaluátoři by dále měli zvážit řadu organizačních a „technických“ opatření, jako je mechanismus administrace nástroje, velikost fontu, výběr vzorku atd. Prevencí prípadných chyb může být i seznámení evaluátora s původními studiemi, ve kterých byly nástroje použity.

Realita programů environmentální výchovy je široká a vyžaduje flexibilitu evaluátora i jeho schopnost otevřít se vevaluaci hledání nových a nevyzkoušených postupů. Předkládaná metodika shrnuje ověřené postupy a diskutuje ty, které dosud v našich podmínkách zcela ověřeny nebyly. Ukazuje na možné strategie pro evaluaci programů, které mohou realizátorům pomoci získat informace důležité pro další vývoj programu. Jejím hlavním cílem je povzbudit odbornou komunitu ke kritickému zkoumání programů a stimulovat tak kvalitativní růst celého oboru. 
SPECIFIKA EVALUACí PROGRAMŮ PRO DĚTI PŘEDŠKOLNÍHO A MLADŠíHO ŠKOLNíHO VĚKU

Předkládaná metodika se soustředí na evaluaci programů určených pro žáky předškolního věku a mladšího školního věku, tj. věkovou skupinou ohraničenou zhruba 12 lety. Věková specifika hrají důležitou roli jednak ve vztahu k samotným programům, jednak k jejich evaluaci.

Dokument Cíle a indikátory EVVO (Broukalová a kol., 2012) vymezil pět hlavních oblastí kompetencí pro environmentálně odpovědné jednání. Těmi jsou:

- Vztah k prírodě

- Vztah k místu

- Ekologické děje a zákonitosti

- Environmentální problémy a konflikty

- Připravenost jednat ve prospěch ŽP

Je možné říct, že pro danou věkovou skupinu je možné zařazovat programy směřující $k$ jakékoliv $z$ těchto oblastí. Na druhé straně je zrejmé, že některé z oblastí jsou pro věkovou skupinu důležité a jiné mohou být naopak problematické.

Pravděpodobně nejdůležitějšími oblastmi kompetencí jsou pro danou věkovou skupinu vztah $\mathrm{k}$ př́rodě a vztah k místu. Zejména pro děti $v$ předškolním věku jsou tyto oblasti, související s rozvijením environmentální senzitivity, tj. vnímáním prírody, utvářením kladných postojủ $\mathrm{k}$ prírodě a propojování se s prírodou, kličové (Simmons et al., 2010; Krajhanzl, 2012).

Význam Ekologických dějů a zákonitostí pak roste zejména s počátkem školní docházky. Zjednodušeně tedy lze říct, že první tři oblasti kompetencí můžeme považovat za stěžejní cíle environmentální výchovy pro toto věkové období1.

Oproti tomu, programy zaměřené na porozumění environmentálním problémům a konfliktům, zejména globálního charakteru, mohou být pro žáky v tomto věku obtižně pochopitelné a emočně zvládnutelné (Krajhanzl, 2012). $Z$ tohoto důvodu bude hlavní důraz $v$ této metodice kladen na evaluaci programů zaměřených na první tři oblasti kompetencí vymezených v Cílech a indikátorech EVVO.

Práce s cílovou skupinou do 12 let je dále specifická z hlediska sběru dat pro evaluační výzkum. Až do zhruba sedmi let nemůžeme předpokládat, že by žáci byli schopni samostatně vyplnit dotazník či test. Nezbytné jsou proto alternativní metody sběru dat. I v pozdějším věku hraje schopnost žáků přečíst zadání a vyplnit test klíčovou roli, která může zásadně ovlivnit výsledky výzkumu. Problémem je také fabulace dětí a jejich snaha odpovídat tak, jak se od nich očekává. Pro hlubší porozumění vývojových specifik cílové skupiny doporučujeme prostudovat publikace z oblasti vývojové psychologie, např. Vágnerová (2012) či Čáp a Mareš (2001). Kromě alternativních metod je proto v evaluacích třeba zvážit možnost získávat data více způsoby a od více typů respondentů: učitelů, rodičů.

Při přípravě každé evaluace je třeba zvážit její kontext. Dotazník, který může být srozumitelný pro jednu skupinu žáků, nemusí být zvládnutelný pro jinou, jde-li např́ilad o skupinu se žáky z imigrantských rodin, 
národnostních menšin nebo s mentálním postižením. Evaluátor by měl proto zvážit schopnosti žáků a flexibilně upravit nástroj či pravidla pro jeho administraci podle aktuální situace. 


\section{VZTAH K PŘíRODĔ}

\section{VYMEZENÍ RÁMCOVÝCH CÍLŮ}

Cíle a indikátory EVVO vymezují v této oblasti čtyři rámcové cíle: potřeba kontaktu s př́rodou, schopnost přímého kontaktu s přírodním prostředím, citlivost $\mathrm{k}$ přírodě a reflexe různých pohledů na prírodu, postojů k ní a ujasňování si vlastních hodnot a postojů (v. tab. č. 1).

Tab. č. 1 Vztah k přírodě v Cílech a indikátorech EVVO

\begin{tabular}{|c|c|c|}
\hline Rámcový cíl & $\begin{array}{l}\text { Vysvětlující komentář (je nutno brát jako } \\
\text { pouze ilustrativní a indikativní výklad) }\end{array}$ & $\begin{array}{l}\text { Orientační př́klady možností ověření, } \\
\text { popř. indikátorů (co je např́klad } \\
\text { možné vyhodnocovat a jakým } \\
\text { nástrojem) }\end{array}$ \\
\hline $\begin{array}{l}\text { Potřeba kontaktu } \\
\text { s př́rodou }\end{array}$ & $\begin{array}{l}\text { - Zájem vyhledávat kontakt s prírodou a } \\
\text { trávit v ní volný čas. }\end{array}$ & $\begin{array}{l}\text { - Množství volného času tráveného } \\
\text { v prírodě (dotazník, rozhovor, } \\
\text { portfolio). } \\
\text { - Analýza výpovědí o subjektivním } \\
\text { prožívání vztahu k přírodě } \\
\text { (rozhovor, volný text, obrazová } \\
\text { reflexe). }\end{array}$ \\
\hline $\begin{array}{l}\text { Schopnost přímého } \\
\text { kontaktu } \\
\text { s přírodním } \\
\text { prostředím }\end{array}$ & $\begin{array}{l}\text { - Připravenost pro kontakt s přírodním } \\
\text { prostředím, aby se člověk v přírodě } \\
\text { zbytečně nebál, neštítil a neprožíval } \\
\text { kontakt s prírodou jako nepohodlný } \\
\text { (zbavení pocitu strachu, odporu apod.). }\end{array}$ & $\begin{array}{l}\text { - Chování jedince či skupiny } \\
\text { v prírodě } \\
\text { pozorování). } \\
\text { - Znalost principů pobytu v prírodě } \\
\text { (dotazník). }\end{array}$ \\
\hline Citlivost k prrírodě & $\begin{array}{l}\text { - Všímavost vưči dění v přírodě. } \\
\text { - Schopnost vyjádřit vlastní prožitek přírody } \\
\text { - slovní, písemné, dramatické, výtvarné, } \\
\text { apod. vyjádření osobního zážitku z } \\
\text { přímého kontaktu s přírodou. } \\
\text { - Vnímavost k potřebám živé prírody. }\end{array}$ & $\begin{array}{l}\text { - Reflektivní zachycení prožitku } \\
\text { prírody - např. jak se v něm } \\
\text { objevuje prríroda, co z přírody, } \\
\text { v jakém kontextu (rozhovor, ústní, } \\
\text { písemná či obrazová reflexe). } \\
\text { - Kvalita péče o živý organismus } \\
\text { (strukturované } \\
\text { rozhovory). } \\
\text { - Znalosti a dovednosti pro kontakt } \\
\text { s živými tvory (dotazník). }\end{array}$ \\
\hline $\begin{array}{l}\text { Reflexe různých } \\
\text { pohledů na přírodu, } \\
\text { postojů k ní a } \\
\text { ujasňování } \\
\text { vlastních hodnot a } \\
\text { postojů }\end{array}$ & $\begin{array}{l}\text { - Reflexe různých hodnotových a etických } \\
\text { pohledů na přírodu. } \\
\text { - Vědomí různosti postojů vůči přírodě. } \\
\text { - Schopnost analýzy hodnotových systémů - } \\
\text { jak se projevují v konkrétních situacích a } \\
\text { jak ovlivňují osobní postoje. } \\
\text { - Vyjádření vlastních hodnot ve vztahu } \\
\text { k prírodě. }\end{array}$ & $\begin{array}{l}\text { - Schopnost přiřadit k určitému } \\
\text { postoji možné hodnotové } \\
\text { východisko (test, rozhovor) } \\
\text { - Schopnost vyjádřit vlastní postoje } \\
\text { a hodnoty k danému problému } \\
\text { (analýza volného textu, eseje, } \\
\text { rozhovor). }\end{array}$ \\
\hline
\end{tabular}




\begin{tabular}{|l|l|l|}
\hline & $\begin{array}{l}\text { Ocenění významu př́rody pro život } \\
\text { člověka. }\end{array}$ & \\
\hline
\end{tabular}

Z hlediska evaluace je možné jednotlivé rámcové cíle propojit s dílčími proměnnými definovanými v rámci existující teorie environmentální výchovy. V následující části se proto pokusíme definovat proměnné, které by bylo možné ověřovat pro jednotlivé rámcové cíle oblasti. Ke každé proměnné pak budou uvedeny příklady jejich možného ověřování v evaluaci programu.

Uvedené proměnné je třeba chápat jako příklady, které nevylučují zařazení dalších proměnných vyplývající z evaluační praxe.

\section{POTŘEBA KONTAKTU S PŘíRODOU}

Prvním rámcovým cílem oblasti Vztah k přírodě je Potřeba kontaktu s prrírodou. $\mathrm{K}$ cíli bylo nadefinováno několik proměnných (v. tab. č. 2):

Tab. č. 2 Potřeba kontaktu s př́rodou

\begin{tabular}{|c|c|c|}
\hline Rámcový cíl & Příklady proměnných & Definice proměnných \\
\hline \multirow[t]{4}{*}{$\begin{array}{l}\text { Potřeba kontaktu } \\
\text { s prírodou }\end{array}$} & Četnost návštěv přírody & $\begin{array}{l}\text { Počet návštěv respondenta v prírodě za určité } \\
\text { časové období. }\end{array}$ \\
\hline & $\begin{array}{l}\text { Pocitovaná potřeba kontaktu } \\
\text { s prírodou }\end{array}$ & $\begin{array}{l}\text { Význam přisuzovaný kontaktu s přírodou } \\
\text { respondentem; míra spokojenosti se stávající } \\
\text { četností kontaktu s prírodou }\end{array}$ \\
\hline & Atraktivita př́rody & $\begin{array}{l}\text { Intenzita zájmu respondenta o návštěvu určité } \\
\text { přírodní lokality nebo o kontakt s určitým přírodním } \\
\text { prvkem. }\end{array}$ \\
\hline & Propojení s prírodou & $\begin{array}{l}\text { Míra, do jaké se lidé cítí propojeni s přírodou, pocit } \\
\text { jednoty s prírodou (Cheng \& Monroe, 2012; Beery, } \\
\text { 2013) }\end{array}$ \\
\hline
\end{tabular}

Potřeba kontaktu s prírodou může být vyhodnocována pomocí kvantitativní i kvalitativní metodologie v závislosti na nastavení programu, cílové skupině i evaluačních otázkách. Pro potřeby evaluace je možné využít široké spektrum nástrojů.

Nejčastější strategií pro měření četnosti návštěv přírody jsou dotazníkové položky, které se ptají respondenta na četnost jeho návštěv prírodního prostředí. Zdánlivá jednoduchost položky ale může zakrýt metodologické problémy. Podívejme se na př́ílad v boxu č. 1:

Box č. 1: Četnost návštěv přírody

Kolikrát jsi byl za posledních 14 dní ve svém volném čase v lese? Zakroužkuj jednu možnost:

Ani jednou -jednou - dvakrát - třikrát - čtyřikrát - pětkrát - šestkrát - sedmkrát -víckrát.

Kolikrát za měsíc zhruba chodíš do lesa (napiš číslo): 
Výhodou prvního příkladu je, že nahrazuje neurčitý pojem "příroda" konkrétním pojmem "les". V případě, že ale výzkum skutečně chce měřit četnost návštěv přírody, může být její náhrada za „les" neakceptovatelná, zejména v regionech, kde je les méně dostupný a je pravděpodobnější, že respondenti častěji chodí například na louku. Pojem „př́roda“ na druhé straně může být respondenty interpretován nejenom jako „les“ či „louka“, ale také jako „zahrada“, „alej stromů u ulice“ či „školní pozemek“. Evaluátor by si měl proto nejprve v diskusi s autory programu ujasnit, jaký význam pojmu „příroda“ zjištovat a jak v důsledku naformulovat př́slušnou položku (problém validity testu a jednotlivých položek).

První varianta položky z boxu č. 1 představuje nucenou možnost, která zkreslí údaje od respondentů s velkou četností návštěv prrírody. Druhá varianta předpokládá, že respondent je schopen počet svých návštěv přírody s rozumnou přesností odhadnout. Pro respondenta je proto náročnější a hrozí, že zejména u mladších respondentů se zde budou objevovat značně nepřesná čísla a že řada z nich tuto položku vynechá.

Dále je třeba zvážit, na jak dlouhou dobu se respondenta dotazujeme. Je zřejmé, že dva týdny mohou být velmi krátká doba a četnost chození do přírody může být ovlivněna faktory, jako jsou například mimořádné školní povinnosti či zdravotní stav respondenta. Měsíc může být na druhou stranu pro mladší respondenty př́liš dlouhá doba na vyhodnocení.

Konečně je třeba promyslet roční období, ve kterém se dotazujeme. Je zřejmé, že četnost návštěv přírody bude jiná v létě než v zimě, o prázdninách a víkendech než ve všedních dnech.

Pocitovaná potřeba kontaktu s přírodou může být vyhodnocována kvalitativně i kvantitativně. V České republice s měřením takové proměnné bohužel zatím chybí zkušenosti. Lze předpokládat, že potřebná data by mohla přinést některá z následujících strategií (v. box č. 2):

Box č. 2 Pocitovaná potřeba kontaktu s př́rodou

Kdybys mohla/-a chodil/-bys do př́rody: častěji než ted' - stejně často - méně často než ted' Jak moc jsi spokojený/-á s tím, jak často jsi v př́rodě:
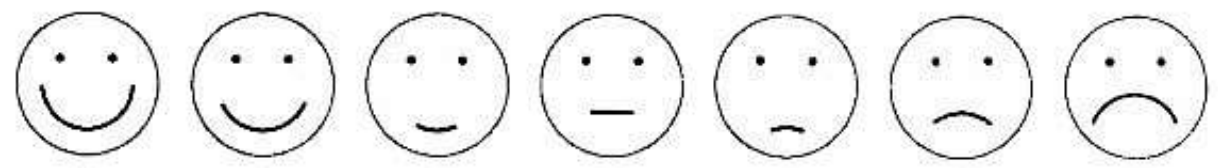

Atraktivita přírody může souviset $s$ atraktivitou určité konkrétní lokality (vztahem k místu). Program environmentální výchovy ovšem může usilovat o zvýšení atraktivity určité složky životního prostředí, nebo o zvýšení atraktivity fyzického kontaktu žáků s přírodou v různých formách.

Např́klad program AQUAMUNDI realizovaný Společností pro Jizerské hory usiluje o zvýšení atraktivity vody. Proměnná byla dále rozdělena na čtyři kategorie, tj. atraktivita fyzického kontaktu s vodou, atraktivita vody jako předmětu prírodovědného a společensko-vědního výzkumu a atraktivita vody jako předmětu umělecké reflexe. Na měření atraktivity vody byl sestaven 13-položkový test využívající pětibodovou „smajlíkovou“ škálu (v. box č. 3): 
Box č. 3 Atraktivita fyzického kontaktu s vodou

Představ si, že máš možnost...

1. ... ... pracovat na školním projektu a zjištovat, jestli je řeka ve Tvojí obci čistá nebo špinavá. Jak by se Ti to líbilo?

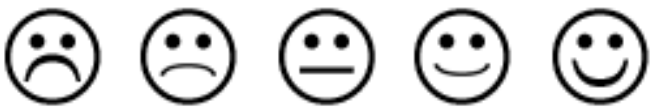

2. ... vykoupat se v létě $v$ horském potoku s čistou a studenou vodou. Jak by se Ti to líbilo?

3. ...zkoumat příběhy lidí, kteří dříve žili u potoka $v$ Tvojí obce. Jak by se Ti to líbilo?

4. ... jít si po škole povídat s odborníkem na zvířata, která žijí ve vodě. Jak by se Ti to líbilo?

5. ... strávit den u potoka zjišt́ováním, jaká v něm žijí zvířata. Jak by se Ti to líbilo?

6. ...chodit v létě po krajině a hledat studánky. Jak by se Ti to líbilo?

7. ...prožít den u jezera a malovat jej. Jak by se Ti to líbilo?

8. ...zapojit se do fotografické soutěže o nejlepší fotku na téma „voda“. Jak by se Ti to líbilo?

9. ... pomocí mikroskopu pozorovat neviditelná zvířátka, která žijí ve vodě? Jak by se Ti to líbilo?

10. ...zkoumat, jak žijí lidé v zemích, kde není dost pitné vody. Jak by se Ti takový úkol líbil?

11. ...být v létě někde, kde se každý den můžeš jít koupat do řeky či rybníka. Jak by se Ti to líbilo?

12. .... zkusit si „přírodní umění - vyrábět sochy z kousků př́rody a kapek vody. Jak by se Ti to líbilo?

13. ...kreslit v zimě sněhové vločky a ledové rampouchy u potoka. Jak by se Ti to líbilo?

Pro měření míry propojení s přírodou pro žáky čtvrté třídy vytvořili Cheng a Monroe (2012) patnácti položkový dotazník s Cronbachovým alfa=0,87. Respondenti odpovídali vždy na pětibodové Likertově škále. Nástroj dosud nebyl v České republice ověřován. Ve volném překladu jej uvádíme v boxu č. 4:

Box č. 4 Propojení s prírodou

1. Rád naslouchám různým zvukům přírody.

2. Rád se v přírodě dívám na volně rostoucí květiny.

3. Když jsem smutný, rád chodím ven a užívám si prírodu.

4. Vždy mě uklidní, když jsem v př́rodě.

5. Rád pracuji na zahradě.

6. Sbírat kameny a mušle je zábava.

7. Mám radost, když jsem venku.

8. Je mi líto, když se ubližuje divokým zvířatům.

9. Rád se dívám na divoká zviřata, jak žijí v čistém životním prostředí.

10. Rád se dotýkám zvírat i rostlin.

11. Je pro mě důležité pečovat o zvířata.

12. Lidé jsou částí přírodního světa.

13. Lidé nemohou žít bez rostlin a zvířat.

14. To co dělám, má význam pro prírodu.

15. Sbíráním odpadků na zemi můžeme pomoci životnímu prostředí.

16. Lidé nemají právo měnit př́rodní prostředí. 


\section{SCHOPNOST PŘÍMÉHO KONTAKTU S PŘÍRODOU}

Rámcový cíl "Schopnost přímého kontaktu s přírodou" otevírá možnost hodnotit nejméně čtyři různé proměnné. Bohužel, řada z nich nebyla dosud v České republice vyhodnocována a postrádáme proto ověřené príklady dobré evaluační praxe.

Tab. č. 3 Schopnost přímého kontaktu s přírodou

\begin{tabular}{|c|c|c|}
\hline Rámcový cíl & Příklady proměnných & Definice proměnných \\
\hline \multirow{4}{*}{$\begin{array}{l}\text { Schopnost } \\
\text { přímého kontaktu } \\
\text { s přírodním } \\
\text { prostředím }\end{array}$} & $\begin{array}{l}\text { Pocitované dovednosti pro } \\
\text { kontakt s př́rodou }\end{array}$ & $\begin{array}{l}\text { Míra přesvědčení (self-efficacy) o zvládnutí } \\
\text { jednotlivých situací souvisejících s pobytem } \\
\text { v prírodě. }\end{array}$ \\
\hline & Strach z prírody & Míra obav z kontaktu s prírodním prostředím. \\
\hline & Znalosti zásad pro pobyt v př́rodě & $\begin{array}{l}\text { Znalost odpovědných variant chování v konkrétních } \\
\text { situacích souvisejících s pobytem v prírodním } \\
\text { prostředí. }\end{array}$ \\
\hline & Odpovědné chování v př́rodě & $\begin{array}{l}\text { Preference odpovědných variant chování } \\
\text { v konkrétních situacích souvisejících s pobytem } \\
\text { v prírodním prostředí. }\end{array}$ \\
\hline
\end{tabular}

Pocitované dovednosti pro kontakt s přírodou mohou být určitou alternativou $k$ měření skutečných dovedností pro pobyt v prírodě. Zatímco skutečné dovednosti by bylo nutné vyhodnocovat pozorováním a vyhodnocováním toho, jak respondent řeší reálné či simulované situace, pocitované dovednosti mohou být vyhodnocovány dotazníkem. Obě varianty můžeme porovnat v boxech č. 5 a 6 .

Box č. 5 Pocit́ované dovednosti pro kontakt s př́rodou

Jak moc si myslíš, že...

... se dokážeš v př́rodě zorientovat podle mapy? Vůbec ne - spíše ne - spíše ano - rozhodně ano

... si dokážeš v prírodě uvařit na vařiči čaj? Vůbec ne - spíše ne - spíše ano - rozhodně ano

Měření pocitovaných dovedností předpokládá sestavení dotazníku. Výhodou tohoto přistupu je jednoduchost ve sběru dat. Přesvědčení o zvládnutí určité kompetence (self-efficacy) je navíc důležitým předpokladem volby určitého chování (Bandura, 1977). Vysoká míra přesvědčení o zvládnutí dovedností pro kontakt s přírodou tedy může odkazovat na vysoké odhodlání respondenta chodit do přírody.

Přesvědčení na druhou stranu nemusí odrážet reálnou dovednost. Pro její vyhodnocení by bylo nezbytné (zejména u mladších dětí) pozorovat respondenta a hodnotit jeho výkon podle předem připravených kritérií (v. box č. 6):

Box č. 6 Př́klad kritérií pro hodnocení dovedností pro pobyt v přírodě: orientace podle mapy

Samostatně našel/-a na mapě svoji pozici:

ANO-NE

Správně podle mapy pojmenoval alespoň jednu lokalitu v okolí: $\quad$ ANO-NE

Správně určil další směr cesty:

ANO-NE 
Strach z přírody může být jednoduše měřen pomocí dotazníku. Rizikem je možná stylizace respondentů, zejména chlapců a jejich nechut' přiznat pravou míru obav.

Příkladem ověřeného nástroje je dotazník Strach z lesa, který byl použit pro evaluaci programu Les ve škole Sdružení TEREZA pro žáky šesté tř́́dy (Činčera, 2012c). Dotazník byl ověřen na množině 70 respondentů průměrného věku 11,7 let, tj. na horní hranici záběru této publikace. Hodnota Cronbachova testu byla vyhodnocena na alfa=0,91. Dotazník se skládal ze tří podškál, tří-položkové škály „sociální ohrožení" (Cronbach alfa=0,76), sedmi-položkové škály „přírodní hrozby“ (Cronbach alfa=0,87) a osmi-položkové „nepříjemné situace v prírodě“ (Cronbach alfa=0,7). Celý dotazník je obsažen v boxu č. 7.

Box č. 7 Dotazník Strach z lesa

Když jsem v lese, bojím se ...

1. ...klíštat:
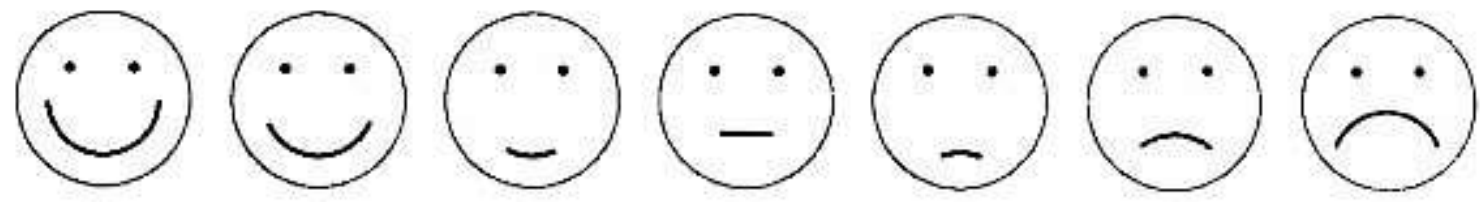

2. ...divokých zvírat:

3. ...že se ztratím

4. ...že se ušpiním

5. ...že se budu nudit

6. ...že potkám vlka

7. ...že mi někdo ublíźí

8. ...že šlápnu do něčeho hodně ošklivého

9. ...že mě uštkne zmije

10. ...že potkám rozzlobené divoké prase

11. ...že mě omylem zastřelí myslivec

12. ...že na mě při bouřce spadne strom

13. ...že potkám pytláka

14. ...že mě kousne sršeň

15. ...že nenajdu cestu domů

16. ...že zmoknu

17. ...že nastydnu

18. ...že ztratím signál mobilu

19. ...že zapadnu do bažiny

20. ...že nebudu vědět, jak se tam mám zabavit 
Znalost zásad pro pobyt v přírodě může být ověřován pomocí jednoduchých testů. Při testování může být tuto proměnnou obtížné odlišit od odpovědného chování v přírodě. Zde se ale kromě testování nabízí ještě využití pozorování respondentů v reálných situacích. Camargo a Shavelson (2009) uvádí několik př́ikladů, jak hodnotit chování účastníků v přirodě pomocí neobtěžujících metod založených na pozorování. Například účinnost vlivu pobytového programu zaměřeného na nepoškozování přírody v průběhu turistické akce byla vyhodnocena tak, že lektoři krátce před odjezdem rozmístili do okolí základny odpadky. Když skupina vyrazila, evaluátor sledoval, kolik žáků bez vyzvání sebralo nějaký odpadek a umístilo jej do blízkého koše.

\section{CITLIVOST K PŘíRODĚ}

Citlivost $\mathrm{k}$ prírodě patří $\mathrm{k}$ nejnáročnějším rámcovým cílům environmentální výchovy. Jedním z důvodů jsou i nejednoznačnosti ve vymezení jednotlivých asociovaných proměnných. Je proto třeba upozornit, že dále uvedené proměnné (v. tab. č. 4) se do určité míry překrývají. Jejich volba pro potřeby evaluace pak může vycházet z orientace programu na určitý diskurs existující v rámci environmentální výchovy.

Tab. č. 4 Citlivost k př́rodě

\begin{tabular}{|c|c|c|}
\hline Rámcový cíl & Příklady proměnných & Definice proměnných \\
\hline \multirow[t]{6}{*}{ Citlivost k prírodě } & Environmentální senzitivita & $\begin{array}{l}\text { Empatická perspektiva k životnímu prostředí, starost } \\
\text { o přírodu (Hungerford \& Volk, 1990; Chawla, 1998) }\end{array}$ \\
\hline & $\begin{array}{l}\text { Sympatie k přírodě (affinity with } \\
\text { nature) }\end{array}$ & $\begin{array}{l}\text { Emoční vazba k př́rodě (Kals, Schumacher \& } \\
\text { Montada, 1999) }\end{array}$ \\
\hline & Vnímavost vůči přírodě & Schopnost reflektovat přírodní vjemy ve svém okolí. \\
\hline & $\begin{array}{l}\text { Pocitované dovednosti pro péči o } \\
\text { živé tvory }\end{array}$ & $\begin{array}{l}\text { Míra přesvědčení (self-efficacy) o zvládnutí } \\
\text { jednotlivých situací souvisejících s péčí o živé tvory. }\end{array}$ \\
\hline & Znalosti zásad pro péči o živé tvory & $\begin{array}{l}\text { Znalost odpovědných variant chování v konkrétních } \\
\text { situacích souvisejících s péčí o živé tvory. }\end{array}$ \\
\hline & $\begin{array}{l}\text { Odpovědné chování k živým } \\
\text { tvorům }\end{array}$ & $\begin{array}{l}\text { Preference odpovědných variant chování } \\
\text { v konkrétních situacích souvisejících s péčí o živé } \\
\text { tvory. }\end{array}$ \\
\hline
\end{tabular}

Environmentální senzitivita je typicky př́kladem složitého konceptu, který je možné chápat i jako synonymum k citlivosti k přírodě či šířeji ke vztahu k přírodě vůbec. Podle Marcinkowskiho (1997) je environmentální senzitivita „osobní smysl pro empatii, blízkost a vztah k přírodnímu prostředí (s. 176). Podle Hungerforda a Volkové (1990) jde o jednu z nejdůležitějších proměnných environmentální výchovy, současně o proměnnou, kterou je obtí̌né cíleně rozvíjet a která vzniká spíše v důsledku dlouhodobé interakce s př́rodou. 
Jednotný není ani způsob, jak environmentální senzitivitu měřit. Podle Nancy Petersonové (2005) Ize koncept environmentální senzitivity propojit s významnými životními zkušenostmi (significant life experience), které respondenty ovlivnily $v$ jejich environmentálním rozhodování. Jednou z možností jsou proto kvalitativní výzkumy založené na rozhovorech s respondenty.

Druhý př́stup prezentuje Sia (in Marcinkowski, 1997), který měřil senzitivitu podle četnosti zážitků respondentů $v$ prírodě (v. box č. 8).

Box č. 8 Př́klad položek v testu environmentální senzitivity

Jak často zažíváte v přírodě tento typ zážitků:

1=nikdy - 2=jednou či dvakrát za rok - 3=zhruba šestkrát za rok - 4=zhruba dvanáctkrát za rok - 5=velmi často

Rodinný výlet do přírodního prostředí:

Rekreace na pramici či kánoi .....

Táboření.....

Sympatie $\mathbf{k}$ prrírodě (affinity with nature) je proměnná, která s environmentální senzitivitou úzce souvisí a v praxi od ní nemusí být snadno rozlišitelná. V rámci evaluace má žrejmě smysl hodnotit jednu či druhou proměnnou. $V$ České republice dosud nebyla tato proměnná na dané věkové skupině měřena.

Pro danou věkovou skupinu by pravděpodobně bylo možné použít nástroj, který vyzkoušeli Kalvaitis a Monhardt (2012) pro hodnocení vztahu dětí ve věku 6-11 let k přírodě. Ve studii dostaly děti za úkol nakreslit obrázek sebe, jak něco dělají v prírodě. Obrázek měly dále písemně popsat a napsat, jaký mají k prírodě vztah. Na splnění dostaly děti papírovou kartičku standardizované velikosti, tužku, pastelky a necelou hodinu času. Děti měly pracovat samostatně.

Analýza využívala statistické i kvalitativní postupy. V obrázcích byly spočítány a kategorizovány jednotlivé prvky, které pak byly statisticky porovnávány mezi různými skupinami respondentů. Hlavní kategorie byly prostředí, lidé, přírodní prvky, aktivity, čas, styl (symbolická či konkrétní prezentace) a tón (pozitivní či negativní). $\checkmark$ textových výpovědích byla kvantifikována četnost výskytu některých slov (např. př́roda, zábava, mít rád atd.).

Někteří autoři definují environmentální senzitivitu jako vnímavost vůči přírodě. Příkladem je Krajhanzl (2010), který senzitivitu definuje jako vnímavost a všímavost vůči přírodě. Člověka s vysokou environmentální senzitivitou podle něj příroda zajímá, „spatří a uslyší to, co mnozí míjejí, ucítí a pocítí to, o čem druzí nemívají ponětí... Je vnímavý ke kráse zdravé přírody i k jejím zraněním a bolestem.“ (s. 28).

Vnímavost vůči přírodě Ize vyhodnocovat pomocí kvalitativních i kvantitativních přistupů. Například cílem programu Les je přítel nabízeného Sdružením TEREZA pro člověka pro první a druhý stupeň základní školy bylo to, že žáci se měli učit „zaměřovat se na jeho vnímání více smysly, vžít se do konkrétního živočicha či rostliny, zkusit vnímat svět jeho očima a reflektovat to a vyjádřit, jak na ně les působil“ (Činčera, 2012a). Evaluace měla odpovědět na otázku, jaký vliv má program na smyslové zážitky, které si děti vybavují z návštěvy lesa. Respondenti nejprve vyplnili jednoduchý dotazník (v. box č. 9) těsně před zahájením programu, stejný dotazník pak vyplnili ve škole v odstupu 1-3 týdny od ukončení programu. 
Box č. 9 Příklad zadání dotazníku na vnímavost přírody z evaluace programu „Les je př́itel“

V rámci dotazníku měli žáci zavzpomínat, jaké to bylo, když byli naposledy v lese. „Stojíš tam, kolem sebe máš stromy..."

Jaké barvy kolem sebe vidíš (napiš nám taky, na čem je vidíš - napríklad „červený list s hnědými tečkami“)

Jaké zvuky kolem sebe slyšiš (napiš nám zase, kdo je asi vydává, a popiš, jak se liší-napřiklad „pták někde za mnou dělá píp-kuňk"):

Na co sis v lese šáhl/-a a jaké to bylo (např. „na pařez, byl suchý a tvrdý“):

Pro vyhodnocení pak byla připravena jednoduchá kódovací tabulka, která umožňovala převést reflexe respondentů na bodovou hodnotu (příklad tabulky v. box č. 10).

Box č. 10 Ukázka kódovací tabulky pro evaluaci programu Les je př́tel

\begin{tabular}{|c|c|c|c|c|}
\hline $\begin{array}{l}\text { Smyslový } \\
\text { vjem }\end{array}$ & Kritérium hodnocení & Modelové situace & Příklad & Hodnocení \\
\hline \multirow[t]{5}{*}{ Zrak } & $\begin{array}{l}\text { Každé nové přiřazení barvy } \\
\text { na předmět v lese, který je } \\
\text { součástí lesního } \\
\text { ekosystému. }\end{array}$ & $\begin{array}{l}\text { Uvedena barva spojená } \\
\text { s předmětem, uvedené spojení } \\
\text { ještě nebylo uvedeno, předmět } \\
\text { je součástí lesního ekosystému }\end{array}$ & Zelené listí & 1 \\
\hline & & $\begin{array}{l}\text { Uvedena barva spojená se dvěma } \\
\text { či více prrírodními předměty }\end{array}$ & $\begin{array}{l}\text { Zelené listí a } \\
\text { jehličí }\end{array}$ & 2 \\
\hline & & Uvedena jen barva & Zelená & 0 \\
\hline & & Uveden jen předmět & Jehličí & 0 \\
\hline & & $\begin{array}{l}\text { Uveden předmět lidského } \\
\text { původu }\end{array}$ & $\begin{array}{l}\text { Červená } \\
\text { čepice }\end{array}$ & 0 \\
\hline
\end{tabular}

Následně pak byla vyhodnocena statistická významnost rozdílů v bodech získaných před a po programu.

Jiný postup zvolili Činčera a Komárková (2010) pro evaluaci volnočasového programu pro děti klientů cestovní kanceláře. Na začátku programu byly děti nejprve požádány, aby nakreslily, jaké to bylo, když byly naposledy v přírodě (v. obr. č. 1). Stejné zadání pak dostaly i na konci pětidenního pobytového programu (v. obr. č. 2). Aby nedošlo k chybné interpretaci, byly děti požádány, aby své obrázky krátce vysvětlily. 
Obr č. 1. Reflexe pobytu v př́rodě před programem - Artur, 7 let

Artur a jeho tatínek při zimních radovánkách

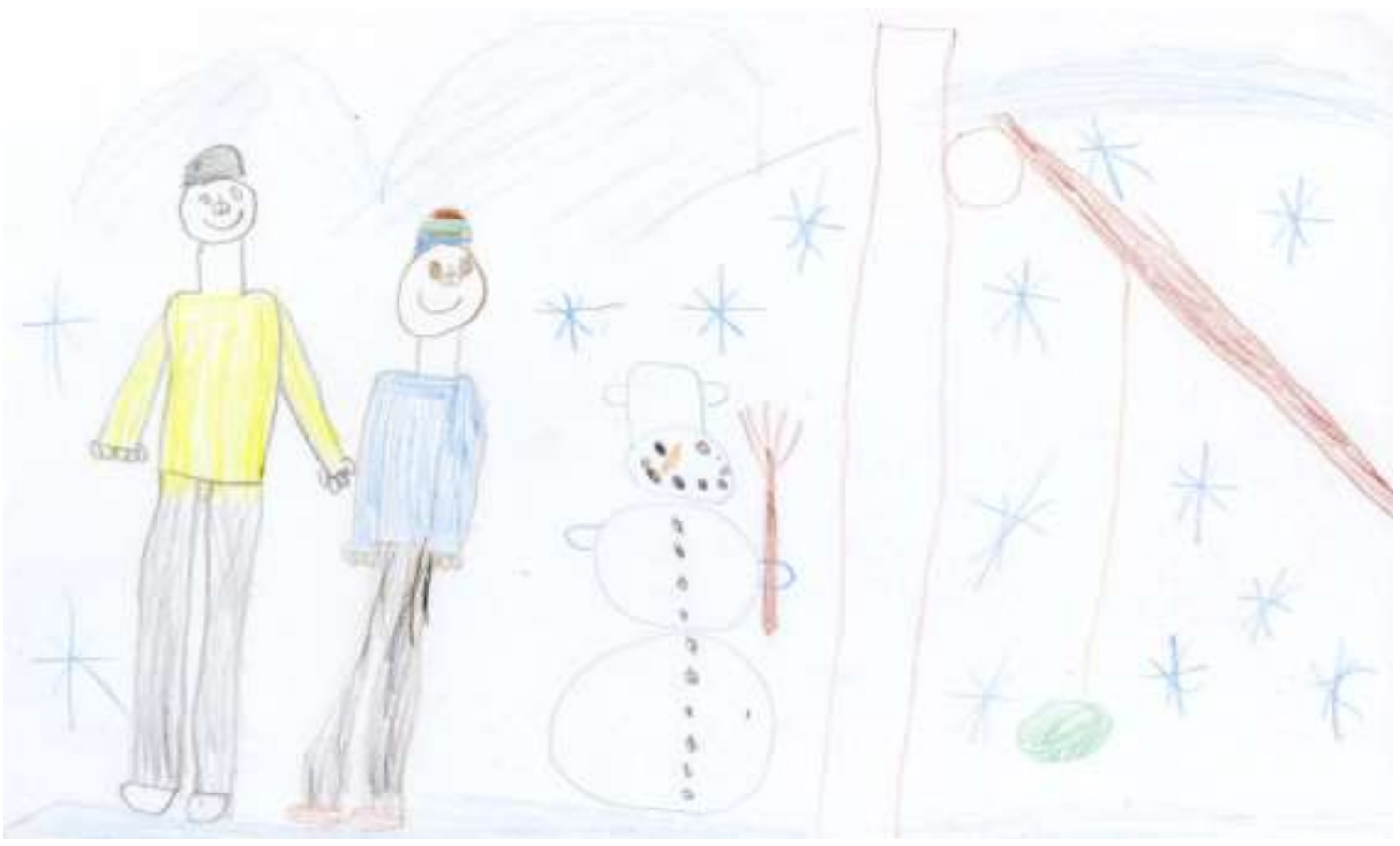

Obr č. 2. Reflexe pobytu v přírodě po programu - Artur, 7 let

Poznávání ptáčků v rámci programu

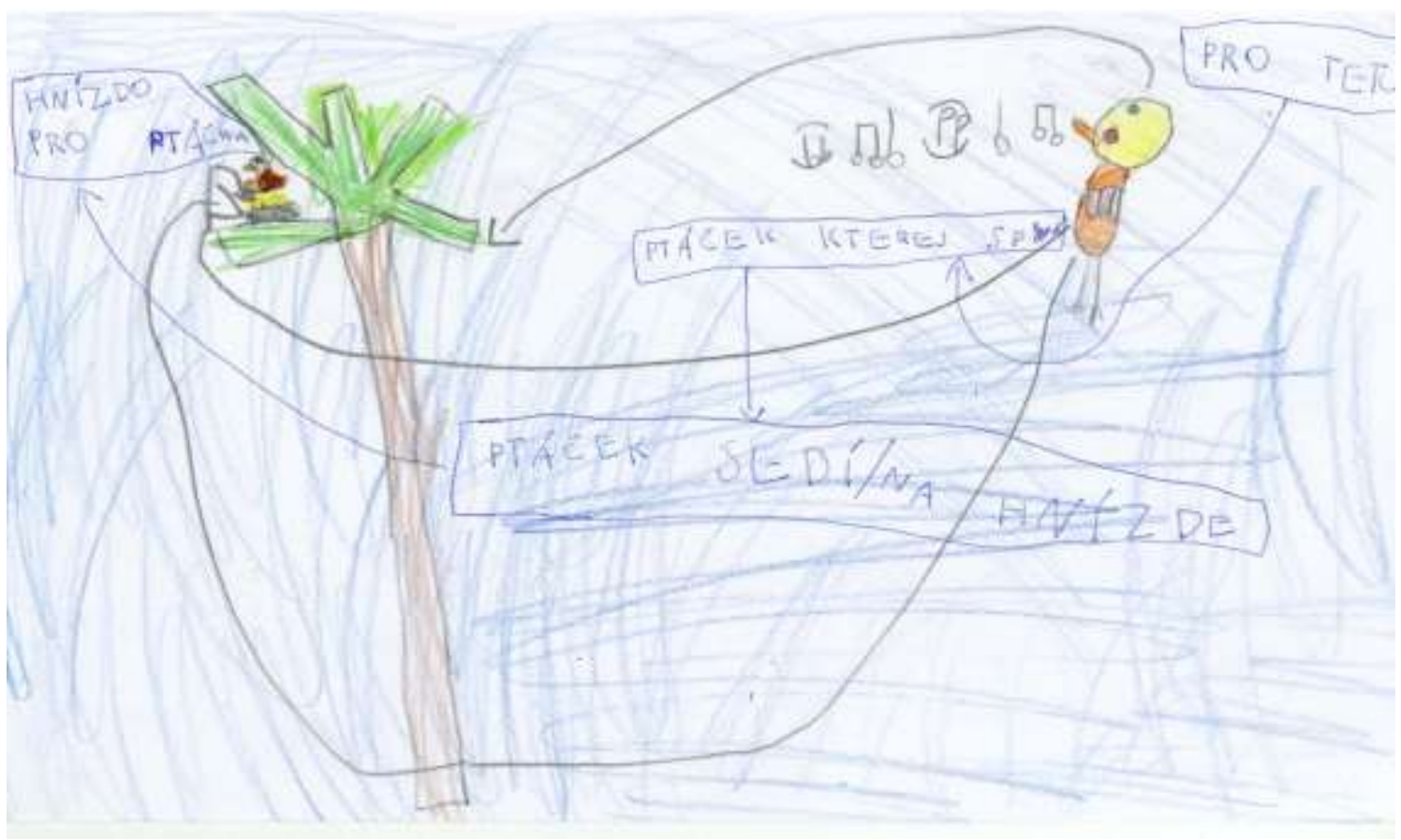

Obrázky byly následně analyzovány podle dvou skupin kategorií. Tou první byla triáda figura, pozadí a aktivita, druhou dyáda přírodní-sociální. Následně byla porovnána četnost výskytu přírodních (zviřata, stromy) x sociálních prvků v pozici figury, pozadí a aktivity před programem a po něm. 
Poslední trojice proměnných, tj. pocitované dovednosti v péči o živé tvory, znalosti zásad pro péči o živé tvory a odpovědné chování $\mathbf{k}$ živým tvorům je analogická proměnným diskutovaným $\mathbf{v}$ kapitole o Schopnosti prrímého kontaktu s přírodou. Můžeme opět předpokládat, že vhodnými nástroji může být dotazník (pocitované dovednosti), test (znalost zásad) či přímé pozorování (odpovědné chování). Bohužel, zkušenosti s měřením těchto proměnných v České republice dosud nejsou k dispozici.

\section{REFLEXE RŮZNÝCH POHLEDU゚ NA PŘíRODU}

Posledním rámcovým cílem v této oblasti jsou reflexe různých pohledů na prírodu (v. tab. č. 5). Zejména první z asociovaných proměnných je velmi často ověřovaná pomocí nástrojů určených pro široké spektrum respondentů.

Tab. č. 5 Reflexe různých pohledů na přírodu

\begin{tabular}{|l|l|l|}
\hline Rámcový cíl & Př́klady proměnných & Definice proměnných \\
\hline $\begin{array}{l}\text { Reflexe různých } \\
\text { pohledů na } \\
\text { př́rodu, postojů } \\
\text { k ní a ujasňování si } \\
\text { vlastních hodnot a } \\
\text { postojů }\end{array}$ & $\begin{array}{l}\text { Postoje k životnímu prostředí } \\
\text { k životnímu prostředí }\end{array}$ & $\begin{array}{l}\text { Pozitivní, negativní či neutrální stanoviska k ochraně } \\
\text { životního prostředí, či př́rody jako celku. }\end{array}$ \\
\cline { 2 - 3 } & \multicolumn{1}{|c|}{ analyzovat postoje } & $\begin{array}{l}\text { Schopnost identifikovat na základě daných situací } \\
\text { postoje jednotlivých osob či skupin k životnímu } \\
\text { prostředía propojit je se souvisejícími hodnotami. }\end{array}$ \\
\hline
\end{tabular}

Nejčastější strategií pro ověřování postoje respondentů k životnímu prostředí je použití dotazníků. Protože jde o poměrně komplexní proměnnou, je vhodné použít již ověřený nástroj se zajištěnou validitou a reliabilitou. Adaptace zahraničních nástrojů pro české prostředí ale může představovat značný problém. Překlad musí být natolik přesný, aby byl srozumitelný pro respondenty a současně neměnil smysl položek. $V$ neposlední řadě nelze vyloučit, že se nástroj v českém prostředí bude chovat kvůli kulturním odlišnostem jinak. Výhodou použití zahraničního nástroje na druhé straně je možnost komunikace a porovnávání výsledků se zahraničními evaluacemi podobných programů.

Nejznámějším nástrojem, který se používá na měření postojů k životnímu prostředí, je tzv. NEP - Nové ekologické paradigma. Nástroj vyvinuli Dunlap a van Liere (1978), v revidované variantě pak Dunlap, van Liere, Mertig a Johnson (2000). Přestože nástroj je standardně používán pro výzkumy dospělých respondentů, $v$ upravené podobě je možné jej použít i pro mladší věkové skupiny.

Wu (2012) ověřoval upravenou variantu NEP pro věkovou skupinu žáků čtvrté až šesté třídy vybraných čínských škol. Respondenty bylo 495 žáků ve věku 10-12 let. Nástroj se skládal z patnácti položek, k nimž se respondenti vyjadřovali na pětibodové Likertově škále (v. box č. 11). Položky, které vyjadřovaly stanoviska opačná k tzv. „novému ekologickému paradigmatu“, byly při zpracování invertovány. 
Box č. 11 NEP pro 10-12 let

1. Země má omezené zdroje a může uživit jen omezený počet obyvatel, současný počet lidí na Zemi se blíží této hranici.

2. Lidé mají právo měnit životní prostředí tak, aby vyhovovalo jejich potřebám.

3. Když lidé zasahují do př́rody, často to vede ke katastrofám či velmi špatným důsledkům.

4. Lidé jsou dost chytří na to, aby zajistili, že na Zemi bude stále možné žít.

5. Lidé vyčerpávají prírodní zdroje nekontrolovaným způsobem, což negativně (špatně) pưsobí na prírodu.

6. Když se lidé naučí, jak využívat zdroje, bude jich na Zemi dost pro lidskou potřebu dost.

7. Všechny živé bytosti (včetně lidí, rostlin a zvírat) mají stejné právo žít na této planetě.

8. Př́roda je dost silná na to, aby zvládla (nebo se vyléčila) z dopadů způsobených současnými aktivitami moderních průmyslově vyspělých zemí.

9. I když mají lidé mimořádné schopnosti (ve srovnání s rostlinami či zvířaty), pořád jsou podřizeni (a měli by respektovat) zákonům prírody.

10. Názor, že „lidé čelí ekologické krizi (či ekologické katastrofě)“ je do značné míry přehnaný.

11. Země (jako kosmická lod') má velmi omezený prostor a zdroje.

12. Lidé jsou páni př́rody, řídí ostatní živé bytosti na planetě.

13. Rovnováha prírody (tj. schopnost přizpůsobovat se a odstraňovat škody) je velmi slabá.

14. Lidé se jednou naučí zákony přírody a budou prírodu řídit.

15. Pokud vše půjde stejně, jako ted', brzy budeme čelit velké ekologické katastrofě.

Pozn.: Nedoporučujeme uvedené položky použít bez předchozího ověření. NEP je velmi citlivý na přesné formulace a špatně zvolená slova mohou změnit jeho interpretaci respondentem. Uvedená verze je neověřený český překlad z autorova (Wu, 2012) překladu nástroje, který byl z původní anglické varianty přeložen do čínštiny, upraven, ověřen a následně znovu přeložen do angličtiny.

Hodnota Cronbachova testu pro dotazník byla alfa=0,65, což Wu (2012) hodnotí jako akceptovatelné. Autor současně upozorňuje na některé specifické problémy nástroje, jako je například nízká korelace položek 1 a 7 . Je možné předpokládat, že po domácím ověření by mohl být NEP pro danou věkovou skupinu použitelný. Vzhledem ke kritice nástroje, která bude podrobněji rozvedena v metodické publikaci pro evaluaci u dospělé klientely, je ale zřejmě vhodnější použít pro měření environmentálních postojů mladších dětí jiný nástroj, případně NEP s jiným nástrojem kombinovat.

Vhodnou alternativou k NEP může být nástroj 2-MEV, který už byl v České republice dostatečně ověřen. Východiskem pro 2-MEV se stal jednak NEP, jednak tzv. Model ekologických hodnot Bognera a Wisemana (in Johnson \& Manoli, 2008, Johnson \& Manoli, 2011), který rozlišuje dvě základní dimenze vnímání životního prostředí: ochranu a využívání prrírody. Faktor Ochrana vyjadřuje ochotu respondenta chovat se šetrně k životnímu prostředí, podporovat ochranu životního prostředí a mít radost z pobytu v přírodě. Faktor Využívání vyjadřuje souhlas s úpravami životního prostředí tak, aby lépe vyhovovalo lidským potřebám a s přesvědčením o právu člověka ovládat prírodu.

Nástroj se skládá ze série tvrzení, kterým se respondenti vyjadřují na Likertově škále (souhlasím-spíše souhlasím-nevím-spíše nesouhlasím-nesouhlasím). Výsledkem pak je zařazení respondenta do některého ze čtyř kvadrantů vyjadřujícího míru zájmu či nezájmu s ochranou př́rody a jejím využíváním. Nástroj byl dále upravován a posléze (pod označením TEQ a později 2-MEV) použit pro evaluace vlivu programů výchovy o Zemi na změnu postojů k životnímu prostředí pro věkovou skupinu 10-12 let (Johnson \& Manoli, 2008). 
Položky 2MEV jsou rozděleny do dvou hlavních a pěti dílčích faktorů:

Ochrana

- Odhodlání k podpoře

- Péče o zdroje

- Radost z prírody

Využívání

- Měnění prírody

- Dominance

V České republice byl nástroj poměrně rozsáhle ověřován. První verze českého překladu byla nejprve použita pro evaluaci programu Vyšetřování katastrofy Jizerských hor se skupinou 53 žáků (Činčera, 2012a). Protože reliabilita nástroje nebyla ideální, byl nástroj znovu přeložen, překlad byl tentokrát konzultován v panelu expertů. Třetí verze překladu byla ústně zadána a diskutována s dvěma respondenty ve věku 10 let. Na základě ověřování proběhly další úpravy překladu. Čtvrtá verze překladu byla následně ověřována na pilotním vzorku sto respondentů. Protože nástroj stále vykazoval dílčí problémy s reliabilitou, byl překlad konzultován s autorem nástroje. Na základě kontroly zpětného překladu některých položek bylo konstatováno, že nástroj je dostatečně reliabilní, současně se ale v některých ohledech chová odlišně od zahraničních zkušeností. Poslední verze překladu byla následně znovu ověřena na skupině 20 respondentů. Nástroj byl poté použit pro evaluaci české verze programu Strážci Země, v současné době zatím na 80 respondentech, průměrný věk přibližně 11 let.

Lze říct, že 2-MEV má výbornou reliabilitu jako celek (Cronbach alfa=0,82), potíže se ale objevují, pokud jej chceme vyhodnocovat podle jednotlivých faktorů. Nástroj předpokládá, že hlavní faktory Ochrana a Využívání spolu negativně korelují, současně že každý z dílčích faktorů koreluje se svým nadřazeným faktorem.

Ověřování nástroje nicméně ukázalo, že tento předpoklad platí jen částečně. Zatímco faktor Ochrana funguje podle očekávání, s faktorem Využívání koreluje pouze dílčí faktor Dominance). Oproti americkým výzkumům je také v Čechách výrazně silnější negativní korelace mezi Ochranou a Využíváním. 
Důvody pro odlišné chování nástroje v českém prostředí mohou být kulturního charakteru. Je možné, že čeští respondenti mají odlišně zorganizovaný systém environmentálních postojů, než američtí. V současné době Ize proto doporučit používat 2-MEV pro analýzu postojů k životnímu prostředí pouze na úrovni nástroje jako celku a nesnažit se o dílčí analýzu podle jednotlivých faktorů. Nástroj jako celek je obsažen v př́loze č. 1.

Z jiné logiky vychází dvojice nástrojů CATES a CATES-PV (Musser a Malkus, 1994; Musser a Diamond, 1999). CATES (v. box č. 12) je 25-položkový dotazník ověřovaný pro žáky 4. a 5. třídy. Nástroj předkládá žákům tvrzení o přesvědčení, emocích a chování v různých oblastech životního prostředí. Hodnota Cronbachova alfa byla naměřena na 0,7 , vyplnění nástroje trvá přibližně dvacet minut.

CATES vždy dává respondentům možnost připodobnit se $\mathrm{k}$ jedné skupině dětí, které bud' zastávají či nezastávají environmentálně příznivý postoj. Každá položka tedy obsahuje stejnou formulaci „Některé děti...“ (popis chování) ALE „jiné děti“ (popis opačného chování). Příklad položek CATES je uveden v boxu č. 12:

Box č. 12 Ukázka položek z nástroje CATES

Některé děti nechávají téct vodu při čištění zubů, ALE jiné děti vodu při čištění zubů vypínají.

Některé děti nerady vyrábí krmítka pro ptáky, ALE jiné děti krmítka pro ptáky vyrábějí rády.

Některé děti netřídí odpad, ALE jiné děti odpad třídí.

Cílem CATES-PV je měřit environmentální postoje předškolních dětí. Nástroj byl odvozen od původního CATES. Byl ověřen na vzorku 42 předškolních žáků (věk od 40 do 73 měsíců), s reliabilitou Cronbach alfa=0,68.

CATES-PV se skládá z 10 položek. U každé položky jsou děti nejprve informovány o souvislosti s určitým environmentálním problémem. Děti pak musí rozhodnout, jakým dětem z příkladu se spíše podobají.

Při zadání dotazníku děti dostaly sadu obrázků ke každé položce. Například na obrázku k položce č. 15 vidí děti dvě dívky, které opouští stejnou místnost. V jednom pokoji je ale zhasnuto, ve druhém je rozsvícená lampa. U každého pokoje je velký kroužek a malý kroužek. Po přečtení položky pak jsou děti požádány, aby označily velký kroužek, pokud se svým chováním hodně podobají chlapci či dívce na jedné straně či malý, pokud se jim podobají jen trochu. Seznam položek v. box č. 13. 
Box č. 13 Seznam položek CATES-PV (varianta pro dívky)

1. Některé dívky nechávají téct vodu při čištění zubů, zatímco jiné dívky při čištění zubů vody vypínají.

2. Některé dívky používají na kreslení či psaní obě strany papíru, zatímco jiné kreslí či píší pouze z jedné strany.

3. Některé dívky si myslí, že bychom měli recyklovat věci, zatímco jiné dívky si myslí, že bychom měli věci, když už je nepotřebujeme, vyhodit.

4. Některé dívky se rády dívají na rostliny a brouky když jsou venku, ale nikdy si je neberou domů. Zato jiné dívky si rády rostliny a brouky, které najdou venku, berou domů.

5. Některé dívky rádi krmí ptáky, zatímco jiné nerady krmí ptáky.

6. Některé dívky myslí, že lidé i zvířata jsou důležití, zatímco jiné dívky si myslí, že zvířata nejsou důležitá.

7. Některé dívky nerady táboří nebo si hrají venku, zatímco jiné dívky rády táboří a hrají si venku.

8. Některé dívky dávají svoje hračky jiným dívkám nebo je dávají k novému využití, když už si s nimi nehrají. Zato jiné dívky svoje hračky vyhazují, když už si s nimi nehrají.

9. Některé dívky nerady sbírají a vyhazují smradlavé odpadky, zatímco jiné dívky odpadky sbírají a vyhazují.

10. Některé dívky třídí lahve a plechovky, aby je mohly recyklovat, zatímco jiné dívky netřídí ani láhve ani plechovky.

11. Některé dívky žijí rádi tam, kde je hodně lidí, zatímco jiné dívky rády žijí tam, kde je hodně rostlin a zvířat.

12. Některé dívky nikdy nesáhnou na zvíře, které najdou venku, zatímco jiné dívky rády sahají na divoká zvírata.

13. Některé dívky rády jezdí autem s jinými dívkami, i když je silný provoz, zatímco jiné dívky nerady jezdí v silném provozu autem.

14. Některé dívky myslí, že divoká zvířata potřebují ochranu, zatímco jiné dívky si myslí, že bychom měli mít možnost lovit a zabíjet všechna divoká zvířata.

15. Některé dívky nechávají v místnosti po odchodu svítit světla, zatímco jiné dívky při odchodu zhasínají světla.

Schopnost analyzovat postoje k životnímu prostředí naopak představuje proměnnou, s jejímž měřením dosud nejsou v České republice zkušenosti. Východiskem mohou být postupy analogické vyhodnocování schopnosti analyzovat postoje a hodnoty zainteresovaných stran environmentálních konfliktů, které budou popsány v navazující metodice. 


\section{VZTAH K MÍSTU}

Vztah k místu je v Cílech a indikátorech EVVO rozdělen do dvou rámcových cílů, tj. znalosti místa a vědomí sounáležitosti (v. tab. č. 6):

Tab. č. 6 Vztah k místu v Cílech a indikátorech EVVO

\begin{tabular}{|c|c|c|}
\hline Rámcový cíl & $\begin{array}{l}\text { Vysvětlující komentář (je nutno brát } \\
\text { jako pouze ilustrativní a indikativní } \\
\text { výklad) }\end{array}$ & $\begin{array}{l}\text { Orientační příklady možností ověření, } \\
\text { popř. indikátorů (co je například možné } \\
\text { vyhodnocovat a jakým nástrojem) }\end{array}$ \\
\hline $\begin{array}{l}\text { Znalost místa, jeho } \\
\text { jedinečnosti a schopnost } \\
\text { interpretovat jej } \\
\text { v souvislostech }\end{array}$ & $\begin{array}{l}\text { - Schopnost popsat čím je určité } \\
\text { místo jedinečné, jak v něm funguje } \\
\text { propojení společnost-příroda, jak se } \\
\text { místo proměňovalo v závislosti na } \\
\text { různých faktorech, jaké jsou citlivé } \\
\text { složky prostředí v místě, jak se místo } \\
\text { odráží v kultuře, príbězích apod. }\end{array}$ & $\begin{array}{l}\text { - Znalost významných míst v krajině, } \\
\text { místních príběhů (test, portfolio, } \\
\text { rozhovor). } \\
\text { - Úroveň percepce (místní) krajiny } \\
\text { (mentální mapy, rozhovor, esej). }\end{array}$ \\
\hline $\begin{array}{l}\text { Vědomí sounáležitosti } \\
\text { s místem a regionem a } \\
\text { pocit zodpovědnosti za } \\
\text { něj }\end{array}$ & $\begin{array}{l}\text { - Schopnost popsat, proč je pro mě } \\
\text { dané místo důležité, jaké lokality } \\
\text { v něm mám rád, co se mi v něm } \\
\text { líbí/nelíbí, co pro místo můžu } \\
\text { udělat, jaké vnímám problémy } \\
\text { místa. }\end{array}$ & $\begin{array}{l}\text { - Ochota trávit v lokalitě volný čas } \\
\text { (dotazník) } \\
\text { - Vztah k místu (dotazník, rozhovor, } \\
\text { esej, volný text, obrazová reflexe). } \\
\text { - Ochota zapojit se do akcí na ochranu } \\
\text { či zkrášlování lokality (dotazník, } \\
\text { sledování účasti na akcích). }\end{array}$ \\
\hline
\end{tabular}

K rámcovým cílům je opět možné definovat vhodné proměnné, kterými se budeme zabývat v následující kapitole.

Tab. č. 7 Proměnné pro Vztah k místu

\begin{tabular}{|c|c|c|}
\hline Rámcový cíl & Příklady proměnných & Definice proměnných \\
\hline \multirow{3}{*}{$\begin{array}{l}\text { Znalost místa, } \\
\text { jeho jedinečnosti } \\
\text { a schopnost } \\
\text { interpretovat jej } \\
\text { v souvislostech }\end{array}$} & Znalost vybraných lokalit v krajině & $\begin{array}{l}\text { Znalost konkrétních míst a schopnost je rámcově } \\
\text { geograficky zařadit. }\end{array}$ \\
\hline & Interpretace místa & $\begin{array}{l}\text { Schopnost interpretovat specifické přírodní či } \\
\text { sociální významové roviny určité lokality. }\end{array}$ \\
\hline & Hodnocení místa & $\begin{array}{l}\text { Schopnost zaujmout pozitivní, negativní či neutrální } \\
\text { stanovisko k různým aspektům krajiny. }\end{array}$ \\
\hline \multirow[t]{2}{*}{$\begin{array}{l}\text { Vědomí } \\
\text { sounáležitosti } \\
\text { s místem a } \\
\text { regionem a pocit } \\
\text { zodpovědnosti za } \\
\text { něj }\end{array}$} & Smysl místa (sense of place) & $\begin{array}{l}\text { Respondentem reflektované propojení s určitým } \\
\text { místem na biofyzikální, psychologické, sociokulturní } \\
\text { a politicko-ekonomické rovině (Ardoin, Schuh \& } \\
\text { Gold, 2012). } \\
\text { Zpravidla obsahuje dvě či více dimenzí, jako je vazba } \\
\text { k mistu a význam mista (Kudryavtsev, Stedman \& } \\
\text { Krasny, 2012). }\end{array}$ \\
\hline & $\begin{array}{l}\text { Vazba k místu (place } \\
\text { attachment) }\end{array}$ & $\begin{array}{l}\text { Pocitóvané pouto mezi respondentem a konkrétním } \\
\text { místem (Kudryavtsev, Stedman \& Krasny, 2012) } \\
\text { V rámci proměnné se někdy rozlišují dalši dimenze, }\end{array}$ \\
\hline
\end{tabular}




\begin{tabular}{|c|c|c|}
\hline & & 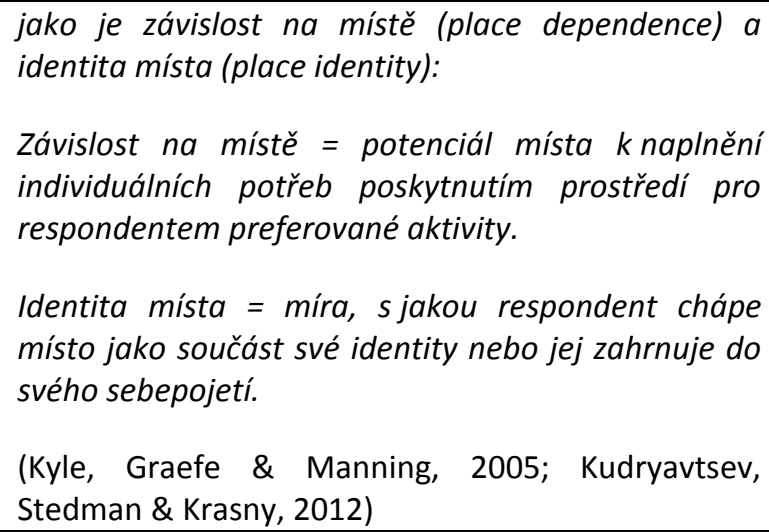 \\
\hline & $\begin{array}{l}\text { Význam místa (place } \\
\text { meaning) }\end{array}$ & $\begin{array}{l}\text { Symbolický } \quad \text { význam pripisovaný místu } \\
\text { respondentem } \\
\text { 2012). }\end{array}$ \\
\hline & Atraktivita místa & $\begin{array}{l}\text { Intenzita zájmu respondenta o návštěvu určité } \\
\text { lokality. }\end{array}$ \\
\hline & Odpovědné chování k místu & $\begin{array}{l}\text { Ochota zapojit se do akcí na ochranu místa; } \\
\text { preference odpovědných variant chování ve vztahu } \\
\text { k místu. }\end{array}$ \\
\hline
\end{tabular}

Přestože k oběma rámcovým cílům je možné nadefinovat nejméně deset různých vzájemně se překrývajících proměnných, pro danou věkovou skupinu téměř nemáme $k$ dispozici ověřené nástroje. Dále uvedené strategie je proto nutno považovat pouze za orientační.

Znalost vybraných lokalit v krajině je možné ověřovat jednoduchým testem, př́padně testem založeným na slepé mapě. Žáci mohou být například požádáni, aby vyjmenovali několik míst v regionu, které považují za důležité, př́padně které by chtěli doporučit návštěvníkovi kraje. Do slepé mapy regionu by pak dané lokality mohli zakreslit.

Schopnost interpretovat místo předpokládá, že respondent vlastními slovy charakterizuje určité rysy lokality, tj. uvede například místní legendy, vysvětlí specifické ekologické rysy lokality nebo poukáže na propojení potřeb lidské společnosti s př́rodou v regionu. Je zřejmé, že uvedené schopnosti mohou být v některých případech nad možnosti dané cílové skupiny. Použitelná strategie pro evaluaci může v tomto prípadě využívat rozhovory s žáky, případně metodu volného textu u starších žáků.

Pro analýzu schopnosti hodnotit místo mohou být žáci požádáni, aby písemnou, ústní či grafickou formou uvedli, jaké části jejich regionu se jim líbí či nelíbí, co by případně chtěli změnit. Pro danou skupinu budou rozhodující roli hrát pravděpodobně kvalitativní metody.

Rozsáhlá skupina proměnných souvisejících se smyslem pro místo (v. obr. č. 3) umožňuje více možností vyhodnocování. 
Obr. č. 3 Proměnné související se smyslem pro místo

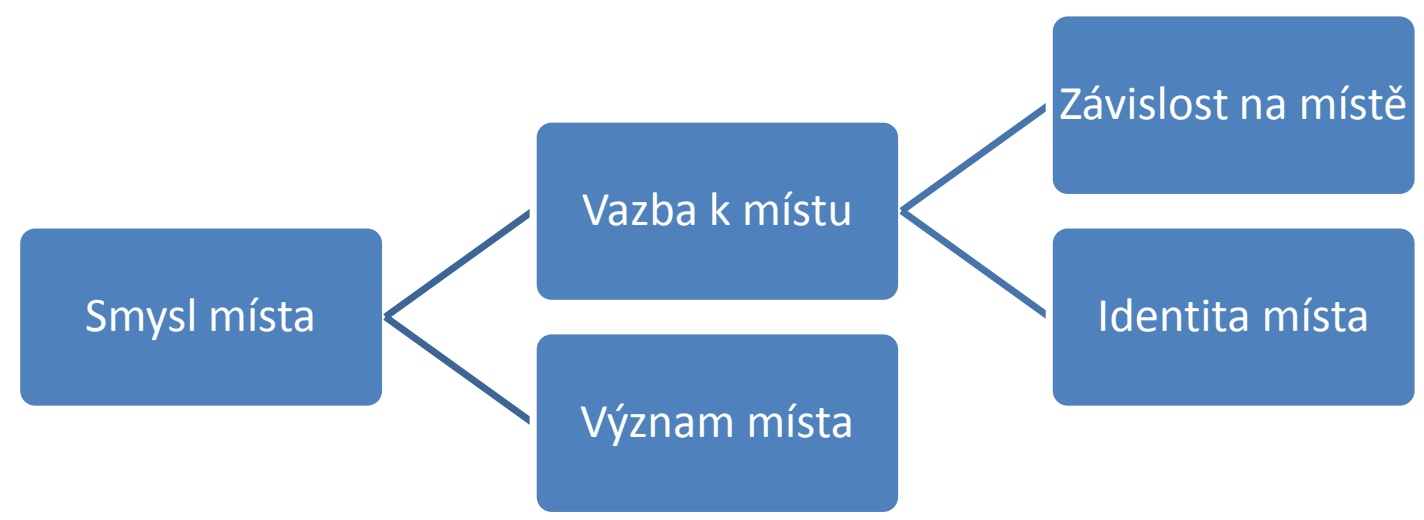

Box č. 14 uvádí př́klady některých strategií doporučovaných Kudryavtsevem a kol. (2012):

Box č. 14 Vybrané strategie $\mathrm{k}$ hodnocení smyslu pro místo

\section{Vazba k místu}

Do jaké míry byste souhlasili s následujícími tvrzeními (1=vůbec ne, 5=rozhodně ano)

Tohle místo je nejlepší místo pro to, co mám rád.

Cítím, že toto místo je část mě samotného.

\section{Význam místa}

Moje jezero je místo, na které utíkám od civilizace.

Doplň odpověd' na otázku:

Co pro tebe toto místo znamená? ......

Podle: Kudryavtsev, Stedman \& Krasny, 2012

Jeden z mála domácích nástrojů pro výzkum této oblasti máme pro výzkum atraktivity určité lokality. Box č. 13 uvádí přehled položek z dotazníku připraveného pro evaluaci vlivu programu Společnosti pro Jizerské hory na atraktivitu Jizerských hor. Dotazník byl poprvé použit pro skupinu 78 respondentů ve věku 10-12 let, kteří se účastnili pobytového programu na Jizerce. Skládá se z jedenácti položek (Cronbach alfa=0,8) (Činčera, 2013). Základní myšlenka je stejná, jako u již uvedeného dotazníku měřícího atraktivitu vody. Žákům jsou nabídnuty různé možnosti aktivit souvisejících s Jizerskými horami, kjejichž atraktivitě se mají vyjádřit na pětibodové Likertově škále. 
Box č. 15 Seznam položek z dotazníku Atraktivita Jizerských hor

Představ si, že máš možnost...

1. ... strávit tři dny chozením po Jizerských horách. Jak by se Ti to líbilo?

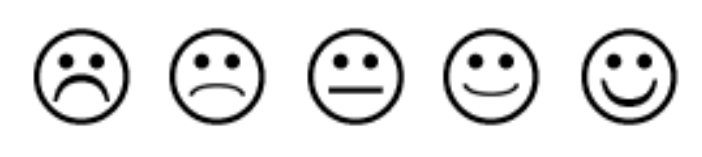

2. ... přečíst si knihu o prírodě a historii Jizerských hor. Jak by se Ti to líbilo?

3. ... navštívit v Jizerkách místo, kde jsi ještě nikdy nebyl/nebyla. Jak by se Ti to líbilo?

4. ... jít po škole na besedu s odborníkem na Jizerské hory. Jak by se Ti to líbilo?

5. ... navštívit v Jizerkách místo, kde jsi ještě nikdy nebyl/-a. Jak by se Ti to líbilo?

6. ...zapojit se do školního projektu o Jizerkách. Jak by se Ti to líbilo?

7. ...vylézt na nejvyšší horu Jizerek Smrk. Jak by se Ti to líbilo?

8. ...zapojit se do práce turistického oddílu, který mapuje v Jizerských horách křižky se zajímavými př́běhy. Jak by se Ti to líbilo?

9. ... zpracovat ve škole samostatný úkol o vzácných kytkách v Jizerských horách. Jak by se Ti to líbilo?

10. ...být v létě na táboře v Jizerských horách. Jak by se Ti to líbilo?

11. ...jet se školou do střediska ekologické výchovy v Jizerských horách. Jak by se Ti to líbilo?

12. ...prozkoumat pravé jizerskohorské bažiny. Jak by se Ti to líbilo?

Pro hodnocení atraktivity určité lokality si Ize dále představit i jiné způsoby měření, například evidenci výpůjček publikací o místě v dané knihovně či účast na volnočasových výletech do lokality. Podobné, neobtěžující metody, by bylo možné použít i pro hodnocení odpovědného chování k místu. Použitelnou strategií by zde mohlo například být zapojování žáků do dobrovolných akcí na pomoc lokalitě (účast na ochranářských brigádách). 


\section{EKOLOGICKÉ DĚJE A ZÁKONITOSTI}

Třetí oblastí, které se zde budeme věnovat, vymezuje pět rámcových cílů environmentální výchovy (v. tab. č. 8):

Tab. č. 8 Ekologické děje a zákonitosti v Cílech a indikátorech EVVO

\begin{tabular}{|c|c|c|}
\hline Rámcový cíl & $\begin{array}{l}\text { Vysvětlující komentář (je nutno brát } \\
\text { jako pouze ilustrativní a indikativní } \\
\text { výklad) }\end{array}$ & $\begin{array}{l}\text { Orientační příklady možností ověření, } \\
\text { popř. indikátorů (co je například možné } \\
\text { vyhodnocovat a jakým nástrojem) }\end{array}$ \\
\hline $\begin{array}{l}\text { Zájem o pochopení } \\
\text { ekologických dějů a } \\
\text { jejich zkoumání }\end{array}$ & $\begin{array}{l}\text { - Vědomí potřebnosti vědeckého } \\
\text { zkoumání ekologických jevů. } \\
\text { - Uvědomění si nejistot v poznání } \\
\text { ekologických dějů } \\
\text { - Vlastní zkušenost se zkoumáním } \\
\text { ekologických dějů a její reflexe. }\end{array}$ & $\begin{array}{l}\text { - } \begin{array}{l}\text { Zájem o odbornou } \\
\text { literaturu } \\
\text { (počet } \\
\text { odborných publikací z knihovickou } \\
\text { dotazník). }\end{array} \\
\text { - Zájem o školní výzkumné projekty } \\
\text { (počet žáků v projektech, dotazník). } \\
\text { - Atraktivita vědecké dráhy v oblasti } \\
\text { ekologie (dotazník, rozhovor, } \\
\text { ohnisková skupina). }\end{array}$ \\
\hline $\begin{array}{l}\text { Schopnosti a dovednosti } \\
\text { pro zkoumání přírody a } \\
\text { životního prostředí }\end{array}$ & $\begin{array}{l}\text { - Porozumění principům zkoumání } \\
\text { prírody. } \\
\text { - Schopnost kritické analýzy informací } \\
\text { o životním prostředí, formulování } \\
\text { otázek, navrhování postupu } \\
\text { výzkumu, sběr dat, vyhodnocení a } \\
\text { interpretace získaných údajů. }\end{array}$ & $\begin{array}{l}\text { - Schopnost zvládnout jednotlivé fáze } \\
\text { vědeckého postupu (portfolio, } \\
\text { pozorování, dovednostní test). }\end{array}$ \\
\hline $\begin{array}{l}\text { Porozumění základním } \\
\text { ekologickým dějům a } \\
\text { zákonitostem }\end{array}$ & $\begin{array}{l}\text { - Osvojení základních termínů } \\
\text { (ekosystém, biodiverzita, ekologická } \\
\text { stabilita, apod.), pochopení } \\
\text { základních procesů (toků energie, } \\
\text { vodního cyklu, koloběhu látek, } \\
\text { vztahů mezi organismy a jejich } \\
\text { prostředím), vývoji populací a } \\
\text { společenstev, apod. }\end{array}$ & $\begin{array}{l}\text { - Porozumění základním pojmům a } \\
\text { odbornému textu (znalostní test). } \\
\text { - Schopnost aplikace principů na } \\
\text { konkrétní jevy (test). }\end{array}$ \\
\hline $\begin{array}{l}\text { Porozumění významu } \\
\text { ekologických dějů a } \\
\text { zákonitostí pro život } \\
\text { člověka }\end{array}$ & 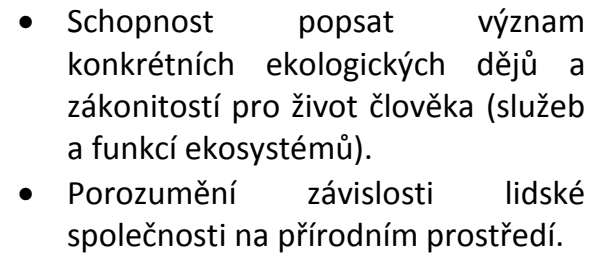 & $\begin{array}{l}\text { - Porozumění provázanosti mezi } \\
\text { člověkem a př́rodou (esej, volný } \\
\text { text, znalostní test, rozhovor). }\end{array}$ \\
\hline $\begin{array}{l}\text { Propojování znalostí } \\
\text { ekologických dějů a } \\
\text { zákonitostí } \\
\text { s každodenním životem }\end{array}$ & $\begin{array}{l}\text { - Schopnost aplikovat ekologické děje } \\
\text { a zákonitosti na prímou životní } \\
\text { zkušenost. }\end{array}$ & $\begin{array}{l}\text { - Schopnost identifikovat dopady } \\
\text { svého chování na životní prostředí } \\
\text { (rozhovor, znalostní test). } \\
\text { - Využití znalostí ekologických dějů } \\
\text { v modelových životních situacích } \\
\text { (projekce, test). }\end{array}$ \\
\hline
\end{tabular}


Příklady možných proměnných jsou uvedeny v tab. č. 9:

Tab. č. 9 Proměnné pro Ekologické děje a zákonitosti

\begin{tabular}{|c|c|c|}
\hline Rámcový cíl & Příklady proměnných & Definice proměnných \\
\hline $\begin{array}{l}\text { Zájem o pochopení } \\
\text { ekologických dějů a } \\
\text { jejich zkoumání }\end{array}$ & Atraktivita ekologie & $\begin{array}{l}\text { Intenzita zájmu respondenta o aktivity související } \\
\text { s ekologickým výzkumem prírody. }\end{array}$ \\
\hline $\begin{array}{l}\text { Schopnosti a dovednosti } \\
\text { pro zkoumání př́rody a } \\
\text { životního prostředí }\end{array}$ & Badatelské dovednosti & $\begin{array}{l}\text { Porozumění badatelskému cyklu a osvojení } \\
\text { dovedností pro jeho jednotlivé fáze, např. formulace } \\
\text { výzkumné otázky, hypotéz, príprava výzkumu, sběr } \\
\text { dat v terénu, vyhodnocení, interpretace a prezentace } \\
\text { dat. }\end{array}$ \\
\hline $\begin{array}{l}\text { Porozumění základním } \\
\text { ekologickým dějům a } \\
\text { zákonitostem }\end{array}$ & $\begin{array}{l}\text { Porozumění ekologickým } \\
\text { konceptům }\end{array}$ & $\begin{array}{l}\text { Schopnost vlastními slovy vysvětlit a na konkrétních } \\
\text { př́kladech doložit vybrané koncepty fungování } \\
\text { přírody, např. cykly, provázanost, změna, potravní } \\
\text { řetězec atd. }\end{array}$ \\
\hline $\begin{array}{l}\text { Porozumění významu } \\
\text { ekologických dějů a } \\
\text { zákonitostí pro život } \\
\text { člověka }\end{array}$ & $\begin{array}{l}\text { Porozumění eko-sociální } \\
\text { provázanosti }\end{array}$ & $\begin{array}{l}\text { Schopnost na konkrétních př́kladech propojit vybraný } \\
\text { ekologický koncept a potřeby lidské společnosti. }\end{array}$ \\
\hline $\begin{array}{l}\text { Propojování znalostí } \\
\text { ekologických dějů a } \\
\text { zákonitostí } \\
\text { s každodenním životem }\end{array}$ & $\begin{array}{l}\text { Porozumění ekologické } \\
\text { provázanosti }\end{array}$ & $\begin{array}{l}\text { Schopnost na konkrétních př́kladech propojit vybraný } \\
\text { ekologický koncept s vlastním chováním. }\end{array}$ \\
\hline
\end{tabular}

$S$ měřením atraktivity ekologie nemáme dosud v českém kontextu zkušenosti. Určitým řešením by mohlo být hodnocení míry zapojení respondentů do aktivity založené na zkoumání přírody. Zajímavý nástroj na měření zapojení žáků ve věku 6-11 let do terénního programu popisuje Ballantyne, Packer a Everett (2005). Použitý záznamový arch předpokládá, že pozorovatel bude zaznamenávat výskyt a intenzitu několika různých jevů (viz box č. 16). 
Box č. 16 Seznam pozorovaných kategorií indikujících zapojení žáků do programu podle Ballantyne a kol. (2005):

1. Sdílení s kamarády

2. Prokazování odpovědnosti za a iniciování vlastního učení (např. znalost žáka co si chce zjistit, rozhodování kam se posunout atd.)

3. Aktivní zapojení do učení (např. stojí a dívají se, čtou, vydrží úkolu, projevují zvědavost...)

4. Záměrná manipulace a hry s objekty a nápady (např. zacházení se vzorky, zájem)

5. Propojování a přenášení nápadů a dovedností (např. povídání o problému, upozorňování, ptaní se ostatních...)

6. Prokazování jistoty v osobních kompetencích (např. vyhledávání informací, vysvětlování spolužákům...)

7. Reakce na nové informace a fakta (např. projevy změny názoru, objevení nových nápadů...)

8. Ztráta pozornosti

\begin{tabular}{|l|l|l|}
\hline Část programu (aktivita) & $\begin{array}{l}\text { Pozorované chování žáků, } \\
\text { komentáře }\end{array}$ & $\begin{array}{l}\text { Frekvence výskytu sledovaných } \\
\text { jevů 1-4 }\end{array}$ \\
\hline & & \\
\hline
\end{tabular}

Badatelské dovednosti mohou být účinněji rozvíjeny patrně až se staršími žáky. Protože ale zkušenosti s programem Badatelé.cz Sdružení TEREZA ukazují, že badatelsky orientované programy mohou fungovat i s mladšími žáky, budeme některé evaluační strategie prezentovat už v této metodice.

Pozoruhodný nástroj vycházející z principů tzv. Vee heuristiky pro semistrukturované rozhovory s 6-7 letými žáky v průběhu jejich badatelského projektu popisuje Vanhear a Pace (2008). Nástroj předpokládá, že evaluátor bude žákům postupně klást otázky, umožňující jim reflektovat proces učení. Nástroj je popsaný v boxu č. 17.

Box č. 17 Vee heuristika pro polostrukturovaný rozhovor podle Vanheara a Pace (2008)

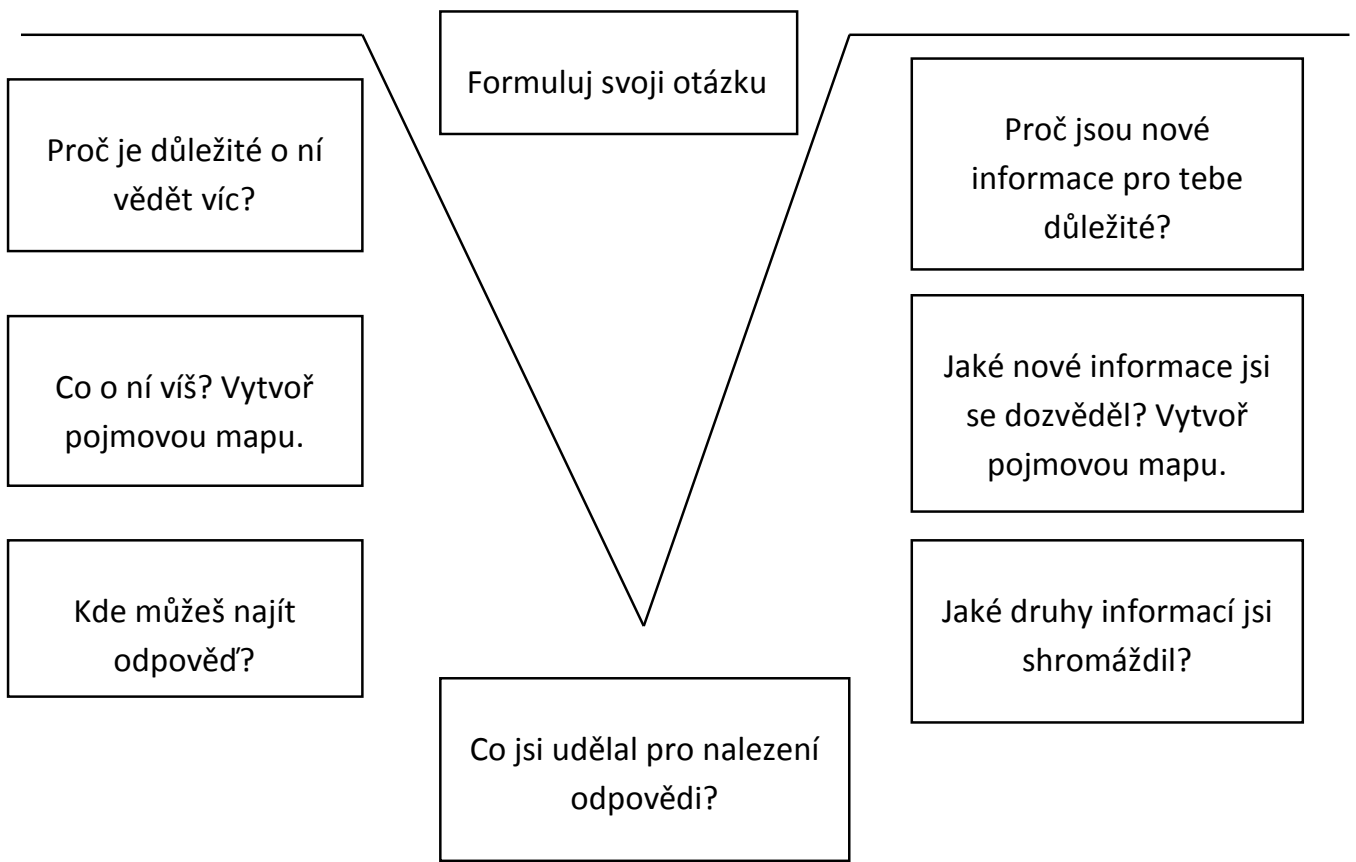


Tazatel postupuje nejprve od horní středové části „V“ levou částí otázek odshora dolů. Otázku spodního hrotu klade ve druhé části badatelského projektu a pokračuje odspodu nahoru pravou částí. Součástí evaluace byly dvě myšlenkové mapy, které žáci vytvářeli ke svému tématu: v první části programu a v závěrečné části.

Nedostatek domácích nástrojů je bohužel limitem i pro následující tři proměnné, tj. porozumění ekologickým konceptům, porozumění eko-sociální provázanosti a porozumění ekologické provázanosti.

Pro zvolení vhodného nástroje může být užitečné ujasnit, zda se v evaluaci soustředit na ověření efektu programu na získání určitých znalostí změnu porozumění probíraného konceptu či schopnost aplikovat získané znalosti v nových situacích.

Pro měření osvojených znalostí doporučuje Marcinkowski (1997) jednoduché testy s výběrem ze dvou či více možností. Příklady takových testů najdeme například v evaluaci Projektu WILD (Fleming, 1983) či ve znalostním testu ECQ, používaném pro evaluaci programů výchovy o Zemi (Johnson, interní dokument) (v. box č. 18).

Box č. 18 Příklady položek na ověřování ekologických znalostí

Který z následujících termínů může být použit jako analogie pro niku:
a) Zaměstnání
b) Habitat
c) Role
d) Adresa
e) $\mathrm{Aic}$
f) $B$ a d

(Marcinkowski, 1997)

Mohla by zvířata žít bez rostlin: ANO - NE

(Fleming, 1983)

Který z následujících příkladů ukazuje správně seřazený potravní řetězec:
a) Slunce $\Rightarrow$ Zvírata $\Rightarrow$ Rostliny
b) Zvírata $\Rightarrow$ Slunce $\Rightarrow$ Rostliny
c) Rostliny $\Rightarrow$ Slunce $\Rightarrow$ Zvírata
d) Slunce $\Rightarrow$ Rostliny $\Rightarrow$ Zvířata

(Johnson, interní dokument)

Klíčové pro vytvoření funkčního testu je ale výběr dostatečně konkrétních konceptů a sestavení baterie položek, které by sestavily reliabilní test. Příkladem takového pokusu může být pěti položkový test, měříí porozumění žáků druhé třídy vodnímu cyklu (v. box č. 19). Test vznikl jako součást evaluace programu Les ve škole Sdružení TEREZA. Vzhledem k problému se získáváním respondentů se ale test nepodařilo dostatečně ověřit. Výsledky na množině dvaceti respondentů udávaly kolísavou úroveň reliability v pre a post-testu. Test proto nelze považovat za dokončený. Zvýšení reliability by mohlo přinést zvýšení počtu položek, další ověřování je ale nezbytné. 
Box č. 19 Ukázka z testu na porozumění vodnímu cyklu

Marta, Patrik a Slávek jsou malé kapky, které prožívají velká dobrodružství. Při nich cestují z místa na místo. Tvým úkolem bude propojit šipkou místa v pořadí, ve kterém je mohly navštívit. Následující obrázek vypráví př́běh Kapky Katky. Podívej se, jak Katka cestovala: (následuje př́klad)

Na začátku príběhu ležela Kapka Katka v kaluži. Protože svítilo slunko, tak se vypařila a stala se z ní pára. Pára se na nebi vysrážela a staly se z ní mraky. Z těch pak Katka stekla zase na zem v podobě deště.

Ted' si to zkus sám/-a. První místo, které každá kapka navštívila, máš od nás dané.

Tohle je dobrodružství Kapičky Marty. Marta poznala spoustu zajímavých míst! Propoj je opět šipkami, v jakém pořadí je nejspíš navštívila:

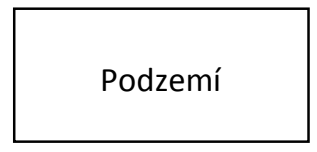

Půda u smrku

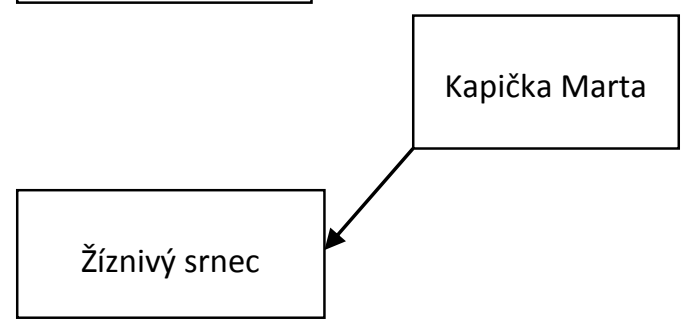

Studánka

Pro vyhodnocení, jaký koncept lesa maji žáci čtvrtých a pátých ročníků základních škol zapojených do programu Les ve škole Sdružení TEREZA byla použita technika myšlenkových map (Činčera, 2012). Žákům byla nejprve na příkladu nesouvisejícím s přírodovědnou problematikou vysvětlena technika myšlenkové mapy. Poté dostali zadání, ve kterém měli doplňovat a propojovat své asociace do několika oblastí, souvisejících s lesem (př́klad zadání v. box č. 20). 
Box č. 20 Zadání myšlenkových map na téma "Les"

Naši spolupracovníci vám ukázali, co to jsou myšlenkové mapy a jak se tvoří. Chtěli bychom Tě ted' poprosit, abys nám v následujících 25 minutách doplnil myšlenkovou mapu o lese.

Ze středu mapy ukazuje pět paprsků. Na čtyřech z nich už jsou napsána témata, která bys měl/-a rozvést:

- Já a les: napiš všechny nápady popisující, co v lese děláš, jak souvisí s Tvým každodenním životem, co pro Tebe les znamená. Čím konkrétněji, tím lépe.

- Jak lidé les ovlivňují: sem napiš všechno o tom, jak lidé les mění, využívají, hospodaří v něm...

- Jak les funguje: čím to je, že les sám od sebe zůstane lesem a nepřemění se třeba na louku? Jaká má les vlastní „pravidla“ fungování?

- Jak les ovlivňuje lidi: k čemu lidi les využívají? Jaký má les vliv na životní prostředí člověka?

Svoje nápady piš do paprsků, které vycházejí z některého z uvedených čtyř. Pátý, prázdný paprsek je pro Tebe. Můžeš do něj vepsat cokoliv, co Tě k lesu napadá a nehodí se do žádného z ostatních čtyř.

Všechny nápady můžeš vzájemně propojovat čárami, pokud mezi nimi objevíš souvislosti.

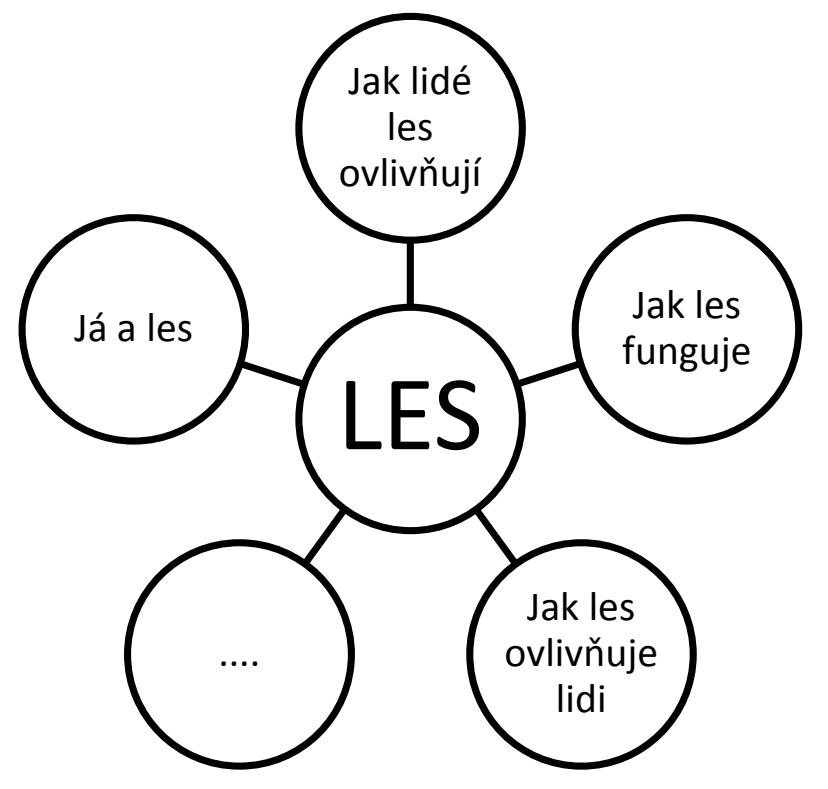

V následující analýze pak byly písemné výpovědi žáků kódovány a převedeny do několika hlavních kategorií (Osobní vztah, vliv člověka, fungování lesa, význam pro člověka, chování v lese), ke kterým byly následně vymezeny dílčí kategorie. Vznikla tak mapa kategorií popisující žákovský koncept lesa (v. obr. č. 7): 
Obr. č. 5 Schéma kategorií pro analýzu myšlenkových map o lese

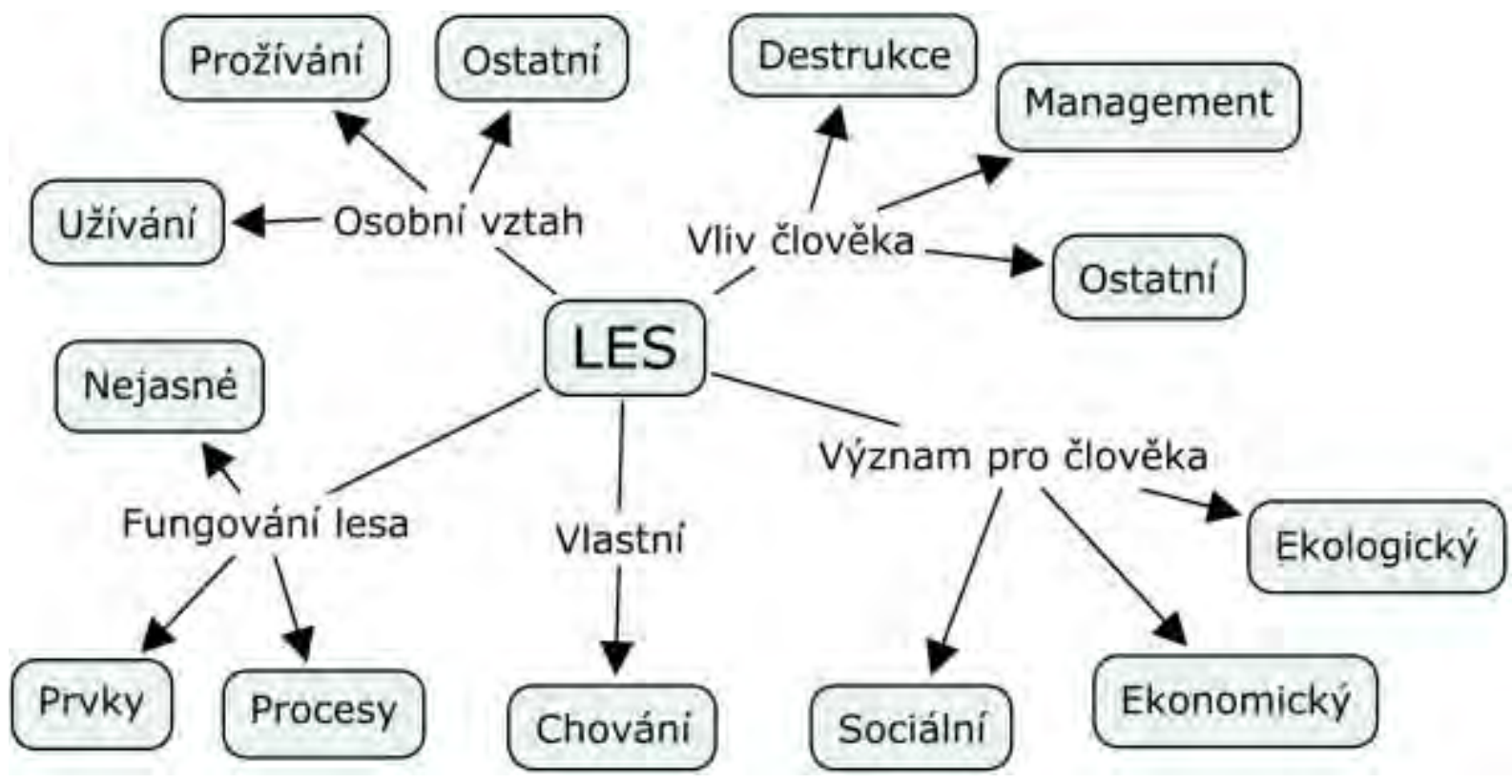

Pro každou kategorií i subkategorii pak byly počíány absolutní a relativní četnosti zařazených výroků. Analýza tedy používala kvalitativní i kvantitativní prvky. 


\section{ENVIRONMENTÁLNÍ PROBLÉMY A KONFLIKTY}

Čtvrtou oblastí vymezenou v Cílech a indikátorech EVVO jsou environmentální problémy a konflikty. Dokument zde definuje tři rámcové cíle (v. tab. č. 10):

Tab. č. 10 Environmentální problémy a konflikty v Cílech a indikátorech EVVO

\begin{tabular}{|c|c|c|}
\hline Rámcový cíl & $\begin{array}{l}\text { Vysvětlující komentář (je nutno brát } \\
\text { jako pouze ilustrativní a indikativní } \\
\text { výklad) }\end{array}$ & $\begin{array}{l}\text { Orientační příklady možností ověření, } \\
\text { popř. indikátorů } \\
\text { (co je například možné vyhodnocovat a } \\
\text { jakým nástrojem) }\end{array}$ \\
\hline $\begin{array}{l}\text { Schopnost analýzy } \\
\text { environmentálních } \\
\text { problémů a konfliktů }\end{array}$ & $\begin{array}{l}\text { - Schopnost vyhledávat a srovnávat } \\
\text { informace o problému a konfliktu } \\
\text { z různých zdrojů, kriticky je zkoumat } \\
\text { a posuzovat. } \\
\text { - Schopnost zkoumat příčiny, } \\
\text { následky, ekonomické, sociální a } \\
\text { historické souvislosti problémů a } \\
\text { konfliktů. } \\
\text { - Schopnost identifikovat názorové } \\
\text { strany konfliktu a analyzovat } \\
\text { hodnoty, přesvědčení a záměry, se } \\
\text { kterými jednotlivé strany do } \\
\text { konfliktu vstupují. }\end{array}$ & $\begin{array}{l}\text { - Znalost vybraných místních i } \\
\text { globálních environmentálních } \\
\text { problémů, jejich příčin, mechanismů } \\
\text { fungování, důsledkům a možným } \\
\text { řešením (znalostní test, rozhovor, } \\
\text { ohnisková skupina, esej, volný text, } \\
\text { portfolio). } \\
\text { - Postoj k závažnosti a možným } \\
\text { řešením problému (dotazník, } \\
\text { rozhovor). identifikovat v textu } \\
\text { - Schopnost jost } \\
\text { environmentální konflikt, jednotlivé } \\
\text { strany konfliktu a jejich postoje } \\
\text { (dovednostní test). }\end{array}$ \\
\hline $\begin{array}{lc}\text { Schopnost } & \text { formulovat } \\
\text { vlastní názor na } \\
\text { problém, posuzovat } \\
\text { variantní řešení a } \\
\text { navrhovat řešení vlastní }\end{array}$ & $\begin{array}{l}\text { - Schopnost porovnávat různé návrhy } \\
\text { na řešení problému a odhadovat } \\
\text { důsledky navržených řešení. } \\
\text { - Schopnost posoudit přijatelnost } \\
\text { navrženého řešení pro různé } \\
\text { názorové strany konfliktu. }\end{array}$ & $\begin{array}{l}\text { - Schopnost zvážit jednotlivé varianty } \\
\text { a navrhnout alternativní řešení } \\
\text { environmentálního konfliktu (esej, } \\
\text { rozhovor, ohnisková skupina, } \\
\text { hodnocení žákovských projektů). }\end{array}$ \\
\hline $\begin{array}{l}\text { Schopnost spolupráce a } \\
\text { komunikace při řešení } \\
\text { environmentálních } \\
\text { konfliktů }\end{array}$ & $\begin{array}{l}\text { - Porozumění významu komunikace a } \\
\text { spolupráce při rešení konfliktů a } \\
\text { důsledkům vznikajícím při odmítání } \\
\text { či porušování těchto principů. } \\
\text { - Dovednost účastnit se a vést diskusi. } \\
\text { - Schopnost hledat a identifikovat } \\
\text { řešení problému, která vycházejí } \\
\text { z principů spolupráce a jsou } \\
\text { přijatelná různými stranami } \\
\text { konfliktu. }\end{array}$ & $\begin{array}{l}\text { - Schopnost vést dialog, metody } \\
\text { rozhodování, ochota zapojit se do } \\
\text { diskuse a řešení (strukturované } \\
\text { pozorování, rozhovory). }\end{array}$ \\
\hline
\end{tabular}

\footnotetext{
2 Problém vzniká v situaci, kdy je ohrožena určitá složka životního prostředí. Konflikty vznikají tehdy, pokud je více názorů na řešení problému.
} 
Tab. č. 11 Proměnné pro Environmentální problémy a konflikty

\begin{tabular}{|c|c|c|}
\hline Rámcový cíl & Příklady proměnných & Definice proměnných \\
\hline \multirow[t]{5}{*}{$\begin{array}{l}\text { Schopnost analýzy } \\
\text { environmentálních } \\
\text { problémů a konfliktů }\end{array}$} & $\begin{array}{l}\text { Environmentální vědomí } \\
\text { (environmental } \\
\text { awareness) }\end{array}$ & $\begin{array}{l}\text { Znalost environmentálních problémů na globální, } \\
\text { národní i regionální úrovni, schopnost pojmenovat } \\
\text { prríčiny i důsledky vyplývající z jejich ekologické, } \\
\text { sociální a ekonomické provázanosti a znalost } \\
\text { základních strategií jejich řešení. }{ }^{3}\end{array}$ \\
\hline & $\begin{array}{l}\text { Environmentální zaujetí } \\
\text { (environmental concern) }\end{array}$ & $\begin{array}{l}\text { Závažnost přisuzovaná environmentálním problémům } \\
\text { a ohrožení životního prostředí (srv. Hansla et al., } \\
\text { 2008). }\end{array}$ \\
\hline & $\begin{array}{l}\text { Vnímané riziko } \\
\text { environmentálního } \\
\text { problému (perceived risk) }\end{array}$ & $\begin{array}{l}\text { Míra závažnosti přisuzovaná konkrétnímu problému } \\
\text { respondentem (srv. Riechard \& Peterson, 1998). }\end{array}$ \\
\hline & $\begin{array}{l}\text { Dovednosti pro analýzu } \\
\text { environmentálních } \\
\text { problémů / konfliktů }\end{array}$ & $\begin{array}{l}\text { Schopnost rozlišit environmentální problém a konflikt, } \\
\text { identifikovat problém a konflikt, pojmenovat } \\
\text { zainteresované strany, určit jejich postoje a hodnoty. }\end{array}$ \\
\hline & $\begin{array}{l}\text { Dovednosti pro výzkum } \\
\text { environmentálního } \\
\text { konfliktu. }\end{array}$ & $\begin{array}{l}\text { Schopnost formulovat si výzkumnou otázku, } \\
\text { navrhnout plán výzkumu, sebrat, vyhodnotit a } \\
\text { prezentovat data související s environmentálním } \\
\text { konfliktem. }\end{array}$ \\
\hline \multirow{2}{*}{$\begin{array}{l}\text { Schopnost formulovat } \\
\text { vlastní názor na } \\
\text { problém, posuzovat } \\
\text { variantní řešení a } \\
\text { navrhovat řešení vlastní }\end{array}$} & $\begin{array}{l}\text { Postoj ke konkrétnímu } \\
\text { environmentálnímu } \\
\text { problému / konfliktu }\end{array}$ & $\begin{array}{l}\text { Názor respondenta na závažnost konkrétního } \\
\text { problému / konfliktu a důležitost jeho řešení. }\end{array}$ \\
\hline & $\begin{array}{l}\text { Schopnost vyhodnotit } \\
\text { alternativní řě̌ení } \\
\text { problému / konfliktu }\end{array}$ & $\begin{array}{l}\text { Pozitivní, negativní či neutrální stanovisko } \\
\text { respondenta na jednotlivá alternativní řešení určitého } \\
\text { problému / konfliktu. }\end{array}$ \\
\hline \multirow{2}{*}{$\begin{array}{l}\text { Schopnost spolupráce a } \\
\text { komunikace při řešení } \\
\text { environmentálních } \\
\text { konfliktů }\end{array}$} & Zapojení do spolupráce & $\begin{array}{l}\text { Míra zapojení respondenta do činnosti skupiny, } \\
\text { spokojenost respondenta se zapojením. }\end{array}$ \\
\hline & $\begin{array}{l}\text { Kvalita komunikace ve } \\
\text { skupině }\end{array}$ & Převládající komunikační mechanismy ve skupině. \\
\hline
\end{tabular}

\footnotetext{
${ }^{3}$ Krajhanzl (2010) definuje environmentální vědomí jako „postoj, který vyjadřuje rozsah a hloubku ochoty k proenvironmentálnímu jednání obecně. S rostoucím environmentálním vědomím se zvyšuje pravděpodobnost (záměrného) proenvironmentálního jednání." (s. 130) S autorem Ize souhlasit v tom, že se tento pojem používá v zahraniční literatuře značně volně. Ve vymezení environmentální výchovy v Tbiliské deklaraci (1977) představují ale postoje jinou kategorii cílů, než environmentální vědomí. Zatímco postojové cíle se zde váží k hodnotám, zaujetí (concern) a motivaci k péči o životní prostředí, cíle v oblasti environmentálního vědomí jsou vymezeny jako „vědomí a citlivost (senzitivita) k životnímu prostredí jako celku a souvisejícím problémům“. Každopádně je třeba připomenout, že uvedené definice jsou v tomto textu míněny jako př́klady a neaspirují na závazné ukotvení v českém diskursu environmentální výchovy.
} 
Vyhodnocování uvedených proměnných není u dané věkové skupiny přiliš časté. Spíše, než hotové nástroje, najdeme proto příklady strategií, které je pro evaluační praxi třeba ještě více či méně přizpůsobit.

Environmentální vědomí u dětí předškolního věku měřili Hungerford a Bryant (1977). Jejich studie hodnotila efekt měsíčního programu zaměřeného na životní prostředí a problémy znečištění pro děti v mateřské škole v Illinois. Cílem bylo zjistit, zda děti po ukončení programu ve srovnání s dětmi, které program neabsolvovaly, identifikují větší počet environmentálních problémů a dokážou vyjádřit osobní odpovědnost svou a ostatních lidí za problémy, které považují za důležité.,

Validita nástroje (v. box č. 21) byla ověřována v panelu tří expertů z oblasti prírodních věd a environmentální výchovy. Všichni nezávisle souhlasili s tím, že nástroj měří to, co má a je konzistentní s cíli programu. Reliabilita testu byla ověřována metodou test-retest.

Box č. 21 Výzkum environmentálního vědomí předškolních dětí

Po ukončení programu dostaly děti ústně čtyři otázky:

1. Jaké nové věci jste se naučily o životním prostředí?

2. Se kterými částmi životního prostředí máme problémy?

3. Co si myslíš, že bys měl/-a s těmi problémy dělat?

4. Co si myslíš, že by s těmi problémy měli dělat jiní lidé?

Každá položka byla hodnocena stejným způsobem. Respondent získával bod za každý související koncept, který uvedl. Pokud tedy respondent na otázku číslo 3 odpověděl: „jezdit na kole a ríct mým rodičům, aby nevypalovali křovi“", získal dva body, protože odkazoval na dva různé způsoby, jak sní̌it znečištění ovzduší. Pokud ale odpověděl „ríct mým rodičům, aby nepálili odpadky a listi“, získal pouze jeden bod, protože odkazoval na stejný koncept ochrany ovzduší.

Design výzkumu byl založený na principu modifikované rotace. Děti byly rozděleny do dvou skupin. Obě skupiny nejprve prošly vstupním modulem programu, který byl nutný pro osvojení slovní zásoby nutné pro pochopení výzkumného nástroje. V prvním měsíci výzkumu byl program realizován s první skupinou ( $\mathrm{N}=17$ ), zatímco druhá $(\mathrm{N}=17)$ měla alternativní program. $V$ obou skupinách byly ale ve stejné době provedeny pretesty a posttesty. Ve druhém měsíci proběhl program ve druhé skupině. Na jeho konci pak v obou skupinách opět proběhly posttesty.

Z vyhodnocování byla posléze vyřazena první položka. Statistická analýza byla provedena pomocí t-testu. Ten pak prokázal efekt programu na sledované proměnné.

Environmentální zaujetí ověřoval u dané cílové skupiny Barraza (1999). Cílem jeho výzkumu bylo ověřit, jak děti vnímají životní prostředí, jejich očekávání a starost o budoucnost. Výzkum proběhl na 741 sedmi až devítiletých dětech v Mexiku a Anglii. Ve výzkumu dostaly děti za úkol nakreslit tři obrázky (v. box č. 22), které pak byly dále kvalitativně analyzovány (hodnotila se např́klad př́tomnost environmentálního problému či typ problému). Celkově děti prokázaly vysokou hladinu environmentálního zaujetí a pesimismus ohledně budoucnosti.

Box č. 22 Environmentální zaujetí

- Ve své kosmické lodi se bližźš planetě Zemi. Nakresli, jak ji vidíš z vesmíru. Jak vypadá?

- Každý z vás přistál na jiném místě. Nikdo tě nemůže vidět, protože jsi neviditelný. Pořádně se kolem rozhlédni a namaluj tolik věcí, kolik můžeš.

- Po padesáti letech opět přistáváš na Zemi. Byl jsi poslán na stejné místo, jako před tím. Namaluj, jak vypadá po tak dlouhé době. 
Podobnou strategii použil pro analýzu vnímání environmentálních rizik také Brown (podle Barraza, 1999), když použil dětské (6-11 let) obrázky na analýzu proměn v jejich vnímání havárie v Černobylu.

$\mathrm{Na}$ ověření dalších proměnných nejsou pro danou věkovou skupinu k dispozici vhodné nástroje. Lze předpokládat, že analýza problémů a konfliktů představuje poměrně náročné téma vhodnější pro starší žáky. Naopak zapojení do spolupráce, kvalitu komunikace či další proměnné související s př́slušným rámcovým cílem vyhodnocovat sdanou skupinou rozhodně Ize. Základní strategií budou zřejmě různé formy strukturovaného, polostrukturovaného či nestrukturovaného pozorování.

Například česko-německý program AQUAMUNDI Společnosti pro Jizerské hory chce zjistit, jakým způsobem v něm probíhá spolupráce mezi českými a německými žáky. Tu má pozorovatel vyhodnocovat pomocí jednoduché observační tabulky (v. box č. 23). Můžeme předpokládat, že podobný nástroj by mohl být využit pro hodnocení spolupráce jiných skupin složených ze dvou částí.

Box č. 23 Observační arch na spolupráci mezi žáky v programu AQUAMUNDI (ukázka)

Název programu:

Datum:

Místo konání:

Pozorovatel: Účastníci Češi (škola, třída): .účastníci Němci (škola/třída):

\begin{tabular}{|c|c|c|c|}
\hline $\begin{array}{l}\text { Čas od } \\
\text { zahájení } \\
\text { (hodina) }\end{array}$ & $\begin{array}{l}\text { Část } \\
\text { programu } \\
\text { (aktivita } \quad- \\
\text { název či } \\
\text { stručný popis) }\end{array}$ & $\begin{array}{l}\text { Pozorované chování žáků, komentáře } \\
\text { (konkrétní příklady pozorovaného chování, přímé citace } \\
\text { výroků, které padly; komentář pozorovatele (uvést vždy } \\
\text { jako K:) ke sledovaným kategoriím či jiným jevům, } \\
\text { potenciálně zajímavým pro evaluaci programu.) }\end{array}$ & $\begin{array}{l}\text { Frekvence } \\
\text { výskytu } \\
\text { sledovaných } \\
\text { jevů } \\
0 \text { (vůbec ne) - } \\
1 \text { (žrídka) - } \\
2 \text { (občas) - } \\
3 \text { (většinou) - } \\
4 \text { (stále) } \\
\end{array}$ \\
\hline $9-10$ & & & $\begin{array}{l}\text { Smk: } \\
0-1-2-3-4 \\
\text { Sms: } \\
0-1-2-3-4 \\
\text { Zda: } \\
0-1-2-3-4 \\
\text { Npc: ........ } \\
\text { Pnz: ........ }\end{array}$ \\
\hline
\end{tabular}

Definice sledovaných kategorií

\begin{tabular}{||l|l|l||}
\hline Kód & Název kategorie & Definice \\
\hline Smk & $\begin{array}{l}\text { Spontánní } \\
\text { mezinárodní } \\
\text { komunikace }\end{array}$ & $\begin{array}{l}\text { Český či německý žák spontánně (tj. bez iniciování učiteli či } \\
\text { vedoucími programu) osloví žáka z druhé země. }\end{array}$ \\
\hline Sms & $\begin{array}{l}\text { Spontánní } \\
\text { mezinárodní } \\
\text { spolupráce }\end{array}$ & $\begin{array}{l}\text { Čeští a němečtí žáci spontánně (tj. bez vyzvání učitelem či vedoucím } \\
\text { programu) spolupracují se svými zahraničními protějšky, tj. např. } \\
\text { spontánně vytváří mezinárodní skupinky, nabízí svoji pomoc. }\end{array}$ \\
\hline Zda & $\begin{array}{l}\text { Zapojení do aktivit } \\
\text { Npc }\end{array}$ & $\begin{array}{l}\text { Většina (až na max 3 výjimky) žáků se aktivně zapojuje do činnosti } \\
\text { související s aktivitou programu. }\end{array}$ \\
\hline Pnz & $\begin{array}{l}\text { Počet nezapojeným } \\
\text { žáků }\end{array}$ & $\begin{array}{l}\text { Počet zpozorovaných případů, ve kterých čeští či němečtí žáci ústně } \\
\text { (např. urážkou) či jinak (např. gestem, postrčením) napadnou své } \\
\text { zahraniční protějšky. }\end{array}$ \\
$\begin{array}{l}\text { Počet žáků vykazujících znaky nezapojení a ignorace nabízených } \\
\text { aktivit či jejich částí kdykoliv ve sledovaném období, tj. např. } \\
\text { nepodílejících se na realizované aktivitě, stojících stranou. }\end{array}$
\end{tabular}




\section{PŘı IPRAVENOST JEDNAT VE PROSPĚCH ŽIVOTNÍHO PROSTŘEDÍ}

Poslední skupinou cílů je Připravenost jednat ve prospěch životního prostředí. Pracovní skupina zde vymezila pět rámcových cílů (v. tab. č. 10):

Tab. č. 12 Připravenost jednat ve prospěch životního prostředí v Cílech a indikátorech EVVO

\begin{tabular}{|c|c|c|}
\hline Rámcový cíl & $\begin{array}{l}\text { Vysvětlující komentář (je nutno brát } \\
\text { jako pouze ilustrativní a indikativní } \\
\text { výklad) }\end{array}$ & $\begin{array}{l}\text { Orientační příklady možností ověření, } \\
\text { popř. indikátorů (co je například možné } \\
\text { vyhodnocovat a jakým nástrojem) }\end{array}$ \\
\hline $\begin{array}{l}\text { Znalost základních } \\
\text { principů } \quad \text { ochrany } \\
\text { životního prostředí }\end{array}$ & $\begin{array}{l}\text { - Porozumění principům ochrany } \\
\text { životního prostředí a udržitelného } \\
\text { rozvoje - např. princip prevence, } \\
\text { princip únosného zatí̌̌ení prostředí, } \\
\text { princip předběžné opatrnosti, } \\
\text { princip odpovědnosti původce } \\
\text { (znečišt́ovatel platí), princip } \\
\text { informovanosti a účasti veřejnosti, } \\
\text { princip zohlednění vztahu „lokální - } \\
\text { globální“ (mysli globálně, jednej } \\
\text { lokálně). }\end{array}$ & $\begin{array}{l}\text { - Porozumění vybraným pojmům } \\
\text { - } \text { (znalostní testy, rozhovory). } \\
\text { ochrany k jednotlivým principům } \\
\text { k ochranè životního prostředí a prostředí na } \\
\text { obecné rovině (dotazník, rozhovor, } \\
\text { esej). }\end{array}$ \\
\hline $\begin{array}{l}\text { Znalosti a dovednosti } \\
\text { potřebné pro šetrné } \\
\text { zacházení s přírodou a } \\
\text { př́rodními zdroji }\end{array}$ & $\begin{array}{l}\text { - Osvojení dovedností pro ohleduplné } \\
\text { jednání vǔči přírodě, pro šetrný } \\
\text { pobyt v přírodě, šetrné využívání } \\
\text { přírody a nakládání s jejími } \\
\text { součástmi. } \\
\text { - Porozumění postupům a } \\
\text { technologickým řešením, která jsou } \\
\text { šetrná k životnímu prostředí zejm. } \\
\text { v oblastech snižování znečištění a } \\
\text { úspor přírodních zdrojů, a schopnost } \\
\text { jejich použití - např. tř́iění odpadů, } \\
\text { využití druhotných surovin a } \\
\text { obnovitelných zdrojů energie, } \\
\text { šetření vodou a elektřinou, výběr } \\
\text { způsobu dopravy, zavádění systémů } \\
\text { environmentálního managementu. }\end{array}$ & $\begin{array}{l}\text { - Znalosti v uvedených oblastech } \\
\text { (znalostní testy). } \\
\text { - } \\
\text { - } \text { (dovednosti v uvedených oblastech } \\
\text { - } \text { rosvědčení o zvládnutí uvedených } \\
\text { - Postoj k danému chování (dotazníky, } \\
\text { rozhovory). } \\
\text { - Odhodlání k danému chování } \\
\text { (dotazník, rozhovor). } \\
\text { - Proenvironmentální chování v dané } \\
\text { oblasti (dotazník, pozorování, } \\
\text { rozhovor). }\end{array}$ \\
\hline $\begin{array}{l}\text { Znalosti a dovednosti } \\
\text { pro } \\
\text { chování }\end{array}$ & $\begin{array}{l}\text { - Znalost environmentálního značení } \\
\text { (ekoznačky - např. EŠV, FSC, Bio), } \\
\text { schopnost posouzení „ekologické } \\
\text { stopy“ (přepravní } \\
\text { vzdálenost, spotřeba energie, } \\
\text { recyklovatelnost apod.), etického a } \\
\text { sociálního rozměru (napr. fair } \\
\text { trade). } \\
\text { - Schopnost posuzovat a předvídat } \\
\text { dopady vlastního jednání na životní } \\
\text { prostředí. }\end{array}$ & $\begin{array}{l}\text { - Znalostní a dovednostní testy, } \\
\text { dotazníky na měření přesvědčení o } \\
\text { zvládnutí dovedností, dotazníky na } \\
\text { měření souvisejících postojů, } \\
\text { dotazníky vyhodnocující chování } \\
\text { respondentů, pozorování, rozhovor } \\
\text { - Znalosti v uvedených oblastech } \\
\text { (znalostní testy). } \\
\text { - Dovednosti v uvedených oblastech } \\
\text { (dovednostní testy, pozorování). } \\
\text { - Postoj k danému chování (dotazníky, } \\
\text { rozhovory). }\end{array}$ \\
\hline
\end{tabular}




\begin{tabular}{|c|c|c|}
\hline & & $\begin{array}{l}\text { - Přesvědčení o zvládnutí uvedených } \\
\text { dovedností (dotazníky, rozhovory). } \\
\text { - Odhodlání k danému chování } \\
\text { (dotazník, rozhovor). } \\
\text { - Proenvironmentální chování v dané } \\
\text { oblasti (dotazník, pozorování, } \\
\text { rozhovor). }\end{array}$ \\
\hline $\begin{array}{l}\text { Znalosti a dovednosti } \\
\text { pro aktivní ovlivňování } \\
\text { svého okolí }\end{array}$ & $\begin{array}{l}\text { - Orientace v legislativním rámci ve } \\
\text { vztahu k životnímu prostředí a účasti } \\
\text { občanů na rozhodování (znalost } \\
\text { práv a povinností, např. právo na } \\
\text { příznivé životní prostředí, právo na } \\
\text { informace, právo na účast } \\
\text { v rozhodování) a schopnost využití } \\
\text { demokratických nástrojů na } \\
\text { prosazování ekologicky př́innivých } \\
\text { řešení (např. zapojení do územního } \\
\text { plánování, do procesu EIA, do } \\
\text { správních řízení, využití petice, } \\
\text { diskuse s volenými zástupci nebo } \\
\text { kandidáty do veřejných funkcí } \\
\text { apod.). }\end{array}$ & $\begin{array}{l}\text { - Znalosti v uvedených oblastech } \\
\text { (znalostní testy). } \\
\text { - Dovednosti v uvedených oblastech } \\
\text { (dovednostní testy, pozorování). } \\
\text { - Postoj k danému chování (dotazníky, } \\
\text { rozhovory). } \\
\text { - Přesvědčení o zvládnutí uvedených } \\
\text { dovedností (dotazníky, rozhovory). } \\
\text { - Odhodlání k danému chování } \\
\text { (dotazník, rozhovor). } \\
\text { - Proenvironmentální chování v dané } \\
\text { oblasti (dotazník, pozorování, } \\
\text { rozhovor). }\end{array}$ \\
\hline $\begin{array}{l}\text { Přesvědčení o vlastním } \\
\text { vlivu na předcházení a } \\
\text { řešení problémů } \\
\text { životního prostředí }\end{array}$ & $\begin{array}{l}\text { - Motivace a ochota k zapojení do } \\
\text { řešení problémů životního prostředí. } \\
\text { - Vědomí / přesvědčení, že svým } \\
\text { jednáním mohu pozitivně ovlivnit } \\
\text { stav životního prostředí. }\end{array}$ & $\begin{array}{l}\text { - Ohnisko kontroly (dotazník, } \\
\text { rozhovor). } \\
\text { - Ochota zapojit se do konkrétních } \\
\text { akcí na ochranu životního prostréedí } \\
\text { (dotazník). }\end{array}$ \\
\hline
\end{tabular}

K rámcovým cílům se opět pokusíme definovat príklady proměnných (v. tab. č. 11):

Tab. č. 13 Proměnné pro Připravenost jednat ve prospěch životního prostředí

\begin{tabular}{|c|c|c|}
\hline Rámcový cíl & Př́klady proměnných & Definice proměnných \\
\hline $\begin{array}{l}\text { Znalost } \quad \text { základních } \\
\text { principů } \quad \text { ochrany } \\
\text { životního prostředí }\end{array}$ & $\begin{array}{l}\text { Environmentální vědomí } \\
\text { (environmental } \\
\text { awareness) }\end{array}$ & $\begin{array}{l}\text { Znalost environmentálních problémů na globální, } \\
\text { národní i regionální úrovni, schopnost pojmenovat } \\
\text { příčiny i důsledky vyplývající z jejich ekologické, } \\
\text { sociální a ekonomické provázanosti a znalost } \\
\text { základních strategií jejich řešení. }\end{array}$ \\
\hline \multirow[t]{2}{*}{$\begin{array}{l}\text { Znalosti a dovednosti } \\
\text { potřebné pro šetrné } \\
\text { zacházení s prrírodou a } \\
\text { prrírodními zdroji }\end{array}$} & $\begin{array}{l}\text { Akční } \quad \text { kompetence } \\
\text { v oblasti šetrného } \\
\text { zacházení s přírodou a } \\
\text { př́rodními zdroji. }\end{array}$ & $\begin{array}{l}\text { Znalosti a dovednosti respondenta potřebné pro } \\
\text { šetrné zacházení s přírodou a prírodními zdroji. }\end{array}$ \\
\hline & 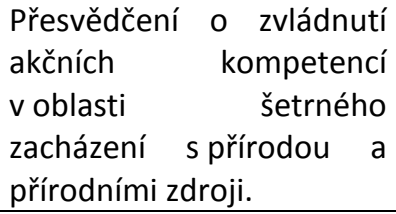 & $\begin{array}{l}\text { Přesvědčení respondenta o míře a kvalitě vlastních } \\
\text { znalostí a dovedností potřebných pro zvážení svého } \\
\text { zacházení s prírodou a prírodními zdroji. }\end{array}$ \\
\hline
\end{tabular}

\footnotetext{
4 Jde o stejnou proměnnou, jako je uvedena v tab. č. 10.
} 


\begin{tabular}{|c|c|c|}
\hline & $\begin{array}{l}\text { Postoje k šetrnému } \\
\text { zacházení s přírodou a } \\
\text { přírodními zdroji. }\end{array}$ & $\begin{array}{l}\text { Pozitivní, negativní či neutrální stanovisko } \\
\text { respondenta k odpovědnému zacházení s př́rodou a } \\
\text { přírodními zdroji na konkrétní či obecné rovině. }\end{array}$ \\
\hline & $\begin{array}{l}\text { Odhodlání k šetrnému } \\
\text { zacházení s př́rodou a } \\
\text { přírodními zdroji. }\end{array}$ & $\begin{array}{l}\text { Míra odhodlanosti respondenta volit v konkrétním } \\
\text { případě či na obecné rovině ve svém nakládání } \\
\text { s prírodou a přírodními zdroji řešení šetrnější } \\
\text { k životnímu prostředí. }\end{array}$ \\
\hline & $\begin{array}{l}\text { Odpovědné } \\
\text { s přírodou a prírodnázeními } \\
\text { zdroji. }\end{array}$ & $\begin{array}{l}\text { Četnost případů volby šetrnějšího nakládání } \\
\text { s prírodou a prírodními zdroji. }\end{array}$ \\
\hline \multirow[t]{5}{*}{$\begin{array}{l}\text { Znalosti a dovednosti } \\
\text { pro } \\
\text { chování }\end{array}$} & $\begin{array}{l}\text { Akční } \\
\text { v oblasti } \\
\text { chování }\end{array}$ & $\begin{array}{l}\text { Znalosti a dovednosti respondenta potřebné pro } \\
\text { zvážení environmentálních dopadů určitého výrobku a } \\
\text { související spotřebitelské chování. }\end{array}$ \\
\hline & $\begin{array}{l}\text { Přesvědčení o zvládnutí } \\
\text { akčních kompetencí } \\
\text { v oblasti spotrebitelského } \\
\text { chování. }\end{array}$ & $\begin{array}{l}\text { Přesvědčení respondenta o míře a kvalitě vlastních } \\
\text { znalostí a dovedností potřebných pro zvážení } \\
\text { environmentálních dopadů určitého výrobku a } \\
\text { související spotřebitelské chování. }\end{array}$ \\
\hline & $\begin{array}{l}\text { Postoje } \\
\text { k spotřebitelskému } \\
\text { chování. }\end{array}$ & $\begin{array}{l}\text { Pozitivní, negativní či neutrální stanovisko } \\
\text { respondenta k odpovědnému spotřebitelskému } \\
\text { chování na konkrétní či obecné rovině. }\end{array}$ \\
\hline & $\begin{array}{l}\text { Odhodlání } \\
\text { k odpovědnému } \\
\text { spotřebitelskému chování. }\end{array}$ & $\begin{array}{l}\text { Míra odhodlanosti respondenta zohlednit } \\
\text { v konkrétním případě či na obecné rovině ve svém } \\
\text { spotřebitelském chování dopady výrobků na životní } \\
\text { prostředí. }\end{array}$ \\
\hline & $\begin{array}{l}\text { Odpovědné spotřebitelské } \\
\text { chování. }\end{array}$ & $\begin{array}{l}\text { Četnost případů zakoupení či nezakoupení určitého } \\
\text { výrobku z důvodu jeho dopadu na životní prostředí. }\end{array}$ \\
\hline \multirow[t]{4}{*}{$\begin{array}{l}\text { Znalosti a dovednosti } \\
\text { pro aktivní ovlivňování } \\
\text { svého okolí }\end{array}$} & $\begin{array}{l}\text { Akční kompetence } \\
\text { v oblasti přesvědčování, } \\
\text { politického a právního } 5 \\
\text { environmentálně } \\
\text { odpovědného chování. }\end{array}$ & $\begin{array}{l}\text { Znalosti a dovednosti respondenta potřebné pro } \\
\text { přesvědčování ostatních, využívání právních nástrojů a } \\
\text { svých politických práv pro dosažení environmentálně } \\
\text { příznivého důsledku. }\end{array}$ \\
\hline & $\begin{array}{l}\text { Přesvědčení o zvládnutí } \\
\text { akčních kompetencí } \\
\text { v oblasti přesvědčování, } \\
\text { politického a právního } \\
\text { environmentálně } \\
\text { odpovědného chování. }\end{array}$ & $\begin{array}{l}\text { Přesvědčení respondenta o míře a kvalitě vlastních } \\
\text { znalostí a dovedností potřebných pro přesvědčování } \\
\text { ostatních, využívání právních nástrojů a svých } \\
\text { politických práv pro dosažení environmentálně } \\
\text { příznivého důsledku. }\end{array}$ \\
\hline & $\begin{array}{l}\text { Postoje } \\
\text { k environmentálně } \\
\text { odpovědnému chování } \\
\text { v oblasti přesvědčování, } \\
\text { politického a právního } \\
\text { chování. }\end{array}$ & $\begin{array}{l}\text { Pozitivní, negativní či neutrální stanovisko } \\
\text { respondenta k přesvědčování, politickému či } \\
\text { právnímu environmentálně odpovědnému chování. }\end{array}$ \\
\hline & $\begin{array}{l}\text { Odhodlání } \\
\text { k přesvědčování, } \\
\text { politickému a právnímu } \\
\text { environmentálně }\end{array}$ & $\begin{array}{l}\text { Míra odhodlanosti respondenta přesvědčovat ostatní, } \\
\text { využívat existující právní nástroje a svá politická práva } \\
\text { pro dosažení environmentálně příznivého důsledku. }\end{array}$ \\
\hline
\end{tabular}

5 Vzhledem k věkové skupině lze předpokládat, že politické a právní kompetence pravděpodobně nebudou v těchto programech aktivně rozvíjeny, ani ověřovány. 


\begin{tabular}{|c|c|c|}
\hline & odpovědnému chování. & \\
\hline & $\begin{array}{l}\text { Environmentálně } \\
\text { odpovědné chování } \\
\text { v oblasti přesvědčování, } \\
\text { politické či právní. }\end{array}$ & $\begin{array}{l}\text { Četnost případů přesvědčování ostatních, využití } \\
\text { existujících právních nástrojů a svých politických práv } \\
\text { pro dosažení environmentálně příznivého důsledku } \\
\text { respondentem. }\end{array}$ \\
\hline \multirow[t]{2}{*}{$\begin{array}{l}\text { Přesvědčení o vlastním } \\
\text { vlivu na předcházení a } \\
\text { řešení problémů } \\
\text { životního prostředí }\end{array}$} & $\begin{array}{l}\text { Environmentální } \\
\text { odpovědnost }\end{array}$ & $\begin{array}{l}\text { Přesvědčení o svém vlivu na životní prostředí, } \\
\text { potenciálu jej pozitivně ovlivňovat a motivace } \\
\text { k odpovědnému environmentálnímu jednání (srv. } \\
\text { Powell a kol, 2011). }\end{array}$ \\
\hline & $\begin{array}{l}\text { Ohnisko kontroly (locus of } \\
\text { control) }\end{array}$ & $\begin{array}{l}\text { Přesvědčení o schopnosti ovlivnit svým jednáním } \\
\text { okolí. (Hungerford \& Volk, 1990; Marcinkowski, 1997) } \\
\text { Ohnisko kontroly může mít interní (je přesvědčen) či } \\
\text { externí (není přesvědčen) hodnotu. Marcinkowski } \\
\text { (1997) dále rozlišuje ohnisko kontroly skupinové či } \\
\text { individuální a specifické (pro určitý problém) či obecné. }\end{array}$ \\
\hline
\end{tabular}

Také v tomto případě nejsou výzkumy související s uvedenými proměnnými u dané věkové skupiny tak časté a ověřené nástroje proto nejsou k dispozici. Dva nástroje byly použity pro evaluaci programu „S TURem zítra tu budem“ Ekocentra Podhoubí na množině 134 dětí z experimentální a 96 z kontrolní skupiny, průměrný věk 1011 let. (Činčera, Fleková a Kopecký, 2011).

Test, měřící akční kompetence v oblasti nakládání s přírodními zdroji seznámil žáky s krátkým příběhem ze života fiktivní Aničky. Žáci pak měli do přiložené dvousloupečkové tabulky identifikovat environmentálně nevhodné chování, kterého se Anička dopustila navrhnout šetrnější alternativu. 
Box č. 24 Test akčních kompetencí

Přečti si Aničky den. Napiš všechno, co v průběhu dne udělala špatně. Ke každé chybě navrhni správné chování.

Anička se ráno probudila a honem si ještě dopsala úkol. Potom se oblékla se a chystala si věci do školy. Nasnídala se a šla do koupelny. Když si čistí zuby, nechává Anička puštěnou vodu, aby se mohla v průběhu čištění zubů kdokoliv napít. Bylo krásné ráno, a tak šla Anička do školy pěšky, místo toho, aby jela autobusem. Ve škole si Anička koupila se svými kamarády svoji nejoblíbenější sušenku. Celou sušenku v obalu si Anička dala jako vždy do igelitového pytlíčku, který si vzala od prodavačky. Po škole Anička dorazila domů. Otevřela dopisní schránku. Našla dopis. Když ho otevřela, zjistila, že je z městského úřadu. Dopis byla pozvánka na veřejnou diskuzi ohledně výstavby nového parku s hřištěm. Anička dopis zmačkala a hodila do modrého kontejneru. Anička si udělala domácí úkoly. Když byl čas jít do postele, převlékla se do pyžama, vyčistila si zuby a šla spát. Anička nechala svůj počítač puštěný přes noc, protože se chce ráno podívat na to, jaké bude počasí. Maminka jí dala dobrou noc a Anička usnula.

Dotazník měříci přesvědčení o zvládnutí akčních kompetencí zaměřený především na oblast šetrného nakládání s přírodními zdroji. Dotazník se skládal ze sedmi položek (Cronbach alfa=0,75). Jeho forma byla odvozena od CATES (Musser a Malkus, 1994). Žáci se tedy také měli rozhodnout, kterému ze dvou uvedených děti se svým chováním více podobají (v. box. č. 25).

Box č. 25 Přesvědčení o akčních kompetencích

1. Adélka umí třídit dobře odpad. Honzík si s tříděním neví rady.

Adélka

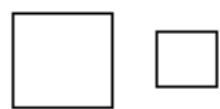

Honzik

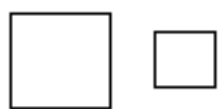

2. Honzík umí nakoupit tak, aby vzniklo co nejméně zbytečného odpadu. Zatímco Adélce to moc nejde.

3. Honzík neumí navrhnout změny, které by vedly k úsporám energie ve škole nebo u něj doma. Zatímco Adélka tyto změny umí navrhnout.

4. Honzík ví, odkud se u něj doma v kohoutku bere pitná voda. Zatímco Adélka si není moc jistá.

5. Adélka neumí poznat dopravní prostředek, který nejméně škodí životnímu prostředí. Zatímco Honzík nejšetrnější dopravní prostředek pozná.

6. Honzík neví, co udělat pro své zdraví. Zatímco Adélka ví, co pro své zdraví udělat.

7. Adélka umí napsat dopis panu řediteli, ve kterém navrhuje změny ohledně šetření energiemi ve škole. Zatímco Honzík takový dopis napsat neumí.

Ani environmentální odpovědnost a ohnisko kontroly nepatři u této věkové skupiny $k$ často měřeným proměnným. Příklady položek pro měření ohniska kontroly uvádí Marcinkowski (1997) (v. box. č. 26): 
Box č. 26 Příklady položek pro měření ohniska kontroly

Do jaké míry věříš, že můžeš ovlivnit řešení environmentálních problémů?

Do jaké míry věříš, že můžeš ovlivnit řešení problému s tříděním odpadů ve vaší obci?

Nabízí se otázka, do jaké míry je spolehlivé měřit tuto proměnnou jedinou položkou, př́ipadně zda položky dotazující se na různé oblasti specifického ohniska kontroly spolu budou korelovat a je možné z nich sestavit spolehlivý test.

Rozdíl mezi ohniskem kontroly a environmentální odpovědností může být v praxi těžko rozeznatelný. Powell a kol. (2011) použili na měření environmentální odpovědnosti u skupiny žáků ve věku 10-15 let šestipoložkový dotazník (v. box. č. 27). Všechny položky využívaly pětibodovou škálu, která vyjadřovala míru souhlasu (pro položky 1-3), úroveň zájmu (položky 4-5) a četnost (položka 6).

Box č. 27 Environmentální odpovědnost

1. Mé jednání ovlivňuje zdraví životního prostředí (míra souhlasu).

2. Je v mých silách pomoci chránit životní prostředí (míra souhlasu).

3. Dokážu ve svém okolí něco změnit (míra souhlasu).

4. Učení se o tom, jak chránit životní prostředí (úroveň zájmu).

5. Práce na zlepšování mého okolí (úroveň zájmu).

6. Budu pracovat pro svoje okolí jako dobrovolník (jak často?)

Celkově ale můžeme shrnout, že tyto proměnné bývají častěji měřeny u starších respondentů, kde je s nimi více zkušeností i v českém prostředí. 


\section{SPOKOJENOST ŽÁKŮ A NEZAMĚŘENÁ EVALUACE PROGRAMU}

Evaluátor se může kromě dohodnutých cílů programu zaměřit také na to, jaký prínos v něm vidí samotní žáci a do jaké míry jsou s programem spokojeni. Přestože obě proměnné mohou být ověřovány v jednom dotazníku, je důležité si uvědomit jejich rozdíly. Spokojenost účastníka s programem můžeme chápat jako postoj k různým aktivitám programu, zázemí, organizaci, lektorům či programu jako celku. Př́nos programu pak odráží to, jaký podle účastníka měl program efekt na ně samotné. Vyhodnocování př́nosu programu tedy koresponduje s východisky tzv. nezaměřené evaluace (goal-free evaluation) programu (Patton, 2002).

Spokojenost účastníka může být vyhodnocována kvalitativně i kvantitativně, nejúčinnější je ale kombinace obou prístupů. Žáci se často nechtějí „rozepisovat“ a pokud evaluátor nemůže předpokládat, že bude mít k dispozici velký počet respondentů a na zadání má jen omezený čas, musí volit „pragmatickou“ variantu.

Příkladem dotazníku měřícího spokojenost žáků s programem Strážci Země pro 4.-5. třídu je nástroj PSS (Johnson, interní dokument). Nástroj kombinuje kvantitativní př́stup, ve kterém žáci vyjadřují souhlas s výroky na čtyřbodové Likertově škále, s kvalitativním, kde jsou jim pokládány otevřené otázky. Př́ílady položek z obou skupin jsou uvedeny v boxu č. 28 :

Box č. 28 Spokojenost žáků s programem Strážci Země - příklady položek

1. Líbilo se mi být venku

2. Aktivity v programu byly nudné

3. Líbili se mi naši vedoucí

4. Aktivity v programu byly moc nudné (....)

Kdybys měl/-a vyprávět kamarádům o programu Strážci Země, co bys jim řekl/-a, aby porozuměli tomu, o co v něm jde?

Příklad krátkého dotazníku měřícího obě proměnné je uveden v príloze č. 2. Dotazník byl připraven pro výzkum programu Badatelé.cz Sdružení TEREZA, varianta pro 4.-5. třídu. První část dotazníku měří spokojenost pomocí čtyř položek, využívá přitom princip sémantického diferenciálu, ve kterém respondenti volí hodnotu mezi dvěma protilehlými pojmy.

Druhá část měří přínosy programu pomocí metody polootevřených vět. Metoda předpokládá, že respondenti v několika slovech napiší, jak by větu chtěli dokončit. Protože výpovědi získané touto metodou bývají poměrně krátké, doporučuje se získané záznamy převést na obecnější kategorie a v nich pak určit absolutní či relativní četnost výroků. Touto metodou může evaluátor zjistit nejsilnější témata, která se v hodnocení př́nosu programu účastníky objevují, a př́padně je porovnat s cíli programu. 


\section{ZÁVĚR}

Metodika uváděla příklady strategií pro evaluaci jednotlivých rámcových cílů environmentální výchovy pro programy nabízené věkové skupině předškolních dětí a dětí mladšího školního věku. Přestože metodika byla ve shodě se zadáním projektu zpracována jako samostatný dokument, pro hlubší porozumění doporučujeme seznámit se i s dalšími souvisejícími texty.

V rámci řešení výzkumného úkolu „Hodnocení efektivity nástrojů environmentálního vzdělávání, výchovy a osvěty (EVVO)" je vydávána trojice postupně navazujících metodik:

- Metodika pro hodnocení programů environmentální výchovy pro předškolní a mladší školní věk

- Metodika pro hodnocení programů environmentální výchovy pro starší školní věk a střední školy.

- Metodika pro hodnocení programů environmentální výchovy pro dospělé účastníky.

Všechny tři metodiky jsou zpracovány stejným způsobem, obsahují některé společné části a vycházejí ze stejného vymezení proměnných pro evaluaci.

V rámci projektu „Hodnocení efektivity nástrojů environmentálního vzdělávání, výchovy a osvěty (EVVO)” dále vycházejí následující studie:

- Střediska ekologické výchovy mezi teorií a praxí. Studie analyzuje, jakým způsobem česká střediska ekologické výchovy zabezpečují efektivitu svých programů a jaké faktory je ovlivňují ve volbě přijatých rozhodnutí.

- Environmentální výchova. Studie vymezuje a charakterizuje základní pojmy v oblasti environmentální výchovy. Popisuje ověřené strategie pro rozvíjení jednotlivých oblastí cílů environmentální výchovy a diskutuje existující problémy.

Projekt současně navazuje na výsledky předchozích projektů. Za klíčové publikace, které vytvářejí jeho kontext, Ize označit následující:

- Cíle a indikátory EVVO (Broukalová a kol., 2012). Dokument vznikl na základě podnětu a potřeb Ministerstva životního prostředí jako výsledek konsensu domácí profesní komunity voblasti environmentální výchovy. Vymezuje a charakterizuje jednotlivé oblasti cílů a rámcové cíle environmentální výchovy.

- Doporučené očekávané výstupy průřezového tématu environmentální výchova (Pastorová a kol., 2011a,b). Publikace vydané Výzkumným ústavem pedagogickým uvádí příklady očekávaných výstupů environmentální výchovy pro základní školy a gymnázia. Převádí tedy obecné cíle do konkrétní a ověřitelné podoby, vhodné pro školní výuku.

- Evaluace programů environmentální výchovy (Činčera, 2010). Metodika pro vedení evaluačního výzkumu programů environmentální výchovy. Publikaci je možné chápat jako společný úvod pro trojici výše uvedených metodik.

Všechny uvedené texty (metodiky, studie i doporučující dokumenty) odrážejí snahu o nové uchopení environmentální výchovy, které by podpořilo účinnou a kritickou reflexi domácích i zahraničních zkušeností a celkový kvalitativní posun oboru. Věŕme, že i předkládaná studie tuto ambici odráží a bude užitečná nejenom pro výzkumníky, ale i pro praktickou část odborné komunity. 


\section{POUŽITÁ LITERATURA}

Ardoin, N. M., Schuh, J. S., \& Gould, R. K. (2012). Exploring the dimensions of place: a confirmatory factor analysis of data from three ecoregional sites. Environmental Education Research, 18(5), 583-607.

Ballantyne, R., Packer, J., \& Everett, M. (2005). Measuring Environmental Education Program Impacts and Learning in the Field: Using an Action Research Cycle to Develop a Tool for Use with Young Students. Australian Journal of Environmental Education, 21, 23-37.

Bandura, A. (1977). Self-efficacy: Toward a Unifying Theory of Behavioral Change. Psychological Review, 84(2), 191-215. Retrieved from http://www.scholaruniverse.com/ncbi-linkout?id=847061 pmid:847061

Barraza, L. (1999). Children's drawings about the environment. Environmental Education Research, 5(1), 49-66.

Beery, T. H. (2013). Establishing reliability and construct validity for an instrument to measure environmental connectedness. Environmental Education Research, 19(1), 81-93.

Broukalová, L. . Cíle a indikátory pro environmentální vzdělávání, výchovu a osvětu v České republice. Praha: Ministerstvo životního prostředí České republiky. Retrieved from http://www.mzp.cz/cz/cile indikatory evvo dokument

Bryant, C. K., \& Hungerford, H. R. (1977). An analysis of strategies for teaching environmental concepts and values clarification in kindergarten. The Journal of Environmental Education, 9(1), 44-49.

Camargo, C., \& Shavelson, R. (2009). Direct Measures in Environmental Education Evaluation: Behavioral Intentions versus Observable Actions. Applied Environmental Education and Communication, 8(3), 165-173.

Čáp, J., \& Mareš, J. (2001). Psychologie pro učitele. Praha: Praha: Portál.

Činčera, J. (2013). Vliv pobytového programu na atraktivitu Jizerských hor. ENVIGOGIKA, 8(1), Retrieved from http://www.envigogika.cuni.cz/index.php/Envigogika/article/view/8 http://dx.doi.org/10.14712/18023061.8

Činčera, J. (2012). Vliv výukového programu na rozvijení environmentální senzitivity žáků. ENVIGOGIKA, 7(2), Retrieved from http://www.envigogika.cuni.cz/index.php/Envigogika/article/view/73 http://dx.doi.org/10.14712/18023061.73

Činčera, J. (2012). Evaluace orientovaná na uživatele: zkušenost s pobytovým programem Člověk a prostředí. Orbis Scholae, 6(3), 119-134.

Činčera, J. (2012). Strach z lesa: vliv programu environmentální výchovy na snižování obav žáků z pobytu v lesním prostředí. Envigogika, 7(2), Retrieved from

http://www.envigogika.cuni.cz/index.php/Envigogika/article/view/74

http://dx.doi.org/10.14712/18023061.74

Činčera, J. (2012). Děti a les. Analýza mentálních map žáků čtvrtých tříd. Envigogika, 7(1), Retrieved from http://www.envigogika.cuni.cz/index.php/Envigogika/article/view/67

http://dx.doi.org/10.14712/18023061.67

Činčera, J. (2011). Doporučené očekávané výstupy pro environmentální výchovu.. Envigogika, 6(2), Retrieved from http://www.envigogika.cuni.cz/index.php/Envigogika/article/view/59

http://dx.doi.org/10.14712/18023061.59 
Činčera, J. (2011). Vliv pobytového programu o Jizerských horách na proenvironmentální postoje a hodnoty. Envigogika, 6(3), Retrieved from http://www.envigogika.cuni.cz/index.php/Envigogika/article/view/8 http://dx.doi.org/10.14712/18023061.8

Činčera, J. (2010). Metodika evaluace programů environmentální výchovy.. Envigogika, 5(3), Retrieved from http://www.envigogika.cuni.cz/index.php/Envigogika/article/view/149

http://dx.doi.org/10.14712/18023061.149

Činčera, J. (2006). Problémy a př́ležitosti environmentální výchovy v České republice. Envigogika, 1(1), Retrieved from http://www.envigogika.cuni.cz/index.php/Envigogika/article/view/9 http://dx.doi.org/10.14712/18023061.9

Činčera, J., Fleková, A., \& Kopecký, J. (2011). S TURem tu i zítra budem": evaluace programu Ekocentra Podhoubí. Envigogika, 6(3), Retrieved from

http://www.envigogika.cuni.cz/index.php/Envigogika/article/view/62

http://dx.doi.org/10.14712/18023061.62

Činčera, J., \& Komárková, M. (2010). Využítí kresby jako prostředku evaluace programu na rozvíjení environmentální senzitivity mladších dětí..Envigogika, 5(2), Retrieved from

http://www.envigogika.cuni.cz/index.php/Envigogika/article/view/53

http://dx.doi.org/10.14712/18023061.53

Činčera, J., Kováčiková, S., Mašková, V., Medal, R., \& Medalová, K. (2012). The Green School: an Impact of Evaluation on Decision-Making about a Program. The New Educational Review, 30(4), 17-29.

Činčera, J., Kulich, J., \& Gollová, D. (2009). Efektivita, evaluace a podpora programů environmentální výchovy. Envigogika. Envigogika, 4(2), Retrieved from

http://www.envigogika.cuni.cz/index.php/Envigogika/article/view/39

http://dx.doi.org/10.14712/18023061.39

Činčera, J., \& Mašková, V. (2011). GLOBE in the Czech Republic: a program evaluation. Environmental Education Research, 17(4), 499-517.

Dunlap, R. E., Van liere, K. D., Mertig, A. G., \& Johnson, R. E. (2000). Measuring endorsement of the new ecological paradigm: A revisited NEP scale.Journal of Social Issues, 56, 425-442.

Dunlap, R. E., \& Van liere, K. D. (1978). The „new environmental paradigm“: A proposed instrument and preliminary results. Journal of Environmental Education, 9(4), 10-19.

Fleming, M. L. (1983). Project WILD Evaluation. Final Report of Field Test. : WREEC.

Hansla, A., Gamble, A., Juliusson, A., \& GÄrling, T. (2008). The relationship between awareness of consequences, environmental concern, and value orientation. Journal of Environmental Psychology, 28(1), 1-9. Retrieved from http://linkinghub.elsevier.com/retrieve/pii/S0272494407000576 http://dx.doi.org/10.1016/j.jenvp.2007.08.004

Hungerford, H. R., \& Volk, T. L. (1990). Changing Learner Behavior through Environmental Education. The Journal of Environmental Education, 21(3), 8-21. Retrieved from

http://www.tandfonline.com/doi/abs/10.1080/00958964.1990.10753743

http://dx.doi.org/10.1080/00958964.1990.10753743

Chawla, L. (1998). Significant life experiences revisited: A review of research on sources of environmental sensitivity. The Journal of Environmental Education, 29(3), 11-21. 
Cheng, J.C. - H., Monroe, M.C., (2012). Connection to Nature: Children's Affective Attitude Toward Nature. Environment and Behavior, 44(1), 31-49.

Johnson, B., \& Manoli, C. C. (2008). Using Bogner and Wiseman's Model of Ecological Values to measure impact on an earth education programme on children's environmental perceptions. Environmental Education Research, 14(2), 115-127.

Johnson, B., \& Manoli, C. C. (2011). The 2-MEV Scale in the United States: A Measure of Children's Environmental Attitudes Based on the Theory of Ecological Attitude. Environmental Education Research, 42(2), 84-94.

Kals, E., Schumacher, D., \& Montada, L. (1999). Emotional affinity towards nature as a motivational basis to protect nature. Environment and Behavior, 31, 178-202.

Kalvaitis, D., \& Monhardt, R. M. (2012). The architecture of children's relationships with nature: a phenomenographic investigation seen through drawings and written narratives of elementary students. Environmental Education Research, 18(2), 209-227. Retrieved from

http://www.tandfonline.com/doi/abs/10.1080/13504622.2011.598227 http://dx.doi.org/10.1080/13504622.2011.598227

Krajhanzl, J. (2010). Charakteristika osobního vztahu k prírodě. Disertační práce. Praha: Praha: Univerzita Karlova.

Krajhanzl, J. (2012). Špetka ekopsychologie pro ekopedagogickou praxi. Úvod do environmentální výchovy a globálního rozvojového vzdělávání. Soubor učebních text. Brno: Lipka.

Kudryavtsev, A., Stedman, R. C., \& Krasny, M. E. (2012). Sense of place in environmental education. Environmental Education Research, 229-250.

Kyle, G., Graeffe, A., \& Manning, R. (2005). Testing the dimensionality of place attachment in recreational settings. Environment and Behavior, 37(2), 153-177. Retrieved from http://eab.sagepub.com/cgi/doi/10.1177/0013916504269654 http://dx.doi.org/10.1177/0013916504269654

Marcinowski, R. J. (1997). Assessment in Environmental Education. Environmental Education. Teacher ressource handbook. A practical guide for K-12 Environmental Education. Thousand Oaks: Corwin Press, 143-199.

Musser, L. M., \& Diamond, K. E. (1999). The Children Attitudes Toward the Environment Scale for Preschool Children. The Journal of Environmental Education, 30(2), 23-30.

Musser, L. M., \& Malkus, A. J. (1994). The Children's Attitudes Toward the Environment Scale. The Journal of Environmental Education, 25(3), 22-26. Retrieved from

http://www.tandfonline.com/doi/abs/10.1080/00958964.1994.9941954 http://dx.doi.org/10.1080/00958964.1994.9941954

Pastorová M. a kol., (2011). Doporučené očekávané výstupy. Metodická podpora pro výuku průřezových témat na základních školách. Praha: Výzkumný ústav pedagogický. Retrieved from http://www.vuppraha.cz/novapublikace-divize-vup-\%E2\%80\%93-doporucene-ocekavane-vystupy-pro-zakladni-skoly

Pastorová, M. a kol, (2011). Doporučené očekávané výstupy. Metodická podpora pro výuku průřezových témat v gymnáziích. Praha: Národní ústav pro vzdělávání, školské poradenské zařizení a zařizení pro další vzdělávání pedagogických pracovníků.. Retrieved from http://digifolio.rvp.cz/artefact/file/download.php?file=35427\&view=4001

Patton, M. Q. (2002). Qualitative Research and Evaluation Methods. Thousand Oaks: Sage. 
Peterson, N. (2005). Factors Influencing the Development of Environmental Sensitivity. Essential Readings in Environmental Education, 295-300.

Powell, R. B., Stern, M. J., Krohn, B. D., \& Ardoin, N. (2011). Development and validation of scales to measure environmental responsibility, character development, and attitudes toward school. Environmental Education Research, 17(1), 91-111.

Riechard, D. E., \& Peterson, S. J. (1998). Perception of environmental risk related to gender, community socioeconomic setting, age, and locus of control.The Journal of Environmental Education, 30(1), 11-19.

SIMMONS B a kol, (2010). Early childhood environmental education programs: Guidelines for Excellence. Washington: NAAEE.

Hungerfors Harold H, , Bluhm William J, , Volk Trudi L, , \& Ramsey John M, (2005). The TBILISI Declaration (1977). Intergovernmental Conference on Environmental Education. Essential Readings in Environmental Education, 13-16.

Vágnerová, M. (2012). Vývojová psychologie - dětství a dospívání. Praha: Praha: Karolinum.

Vanhear, J., \& Pace, P. J. (2008). Integrating knowledge, feelings and action: using VEE heuristics and concept mapping in education for sustainable development. Journal of Teacher Education for Sustainability, 10, 42-54.

Wu, L. (2012). Exploring the New Ecological Paradigm Scale for Gauging Children's Environmental Attitudes in China. The Journal of Environmental Education, 43(2), 107-120. 


\section{PŘ́ĺLHY}

PŘíLOHA Č. 1 2-MEV

Ahoj,

Pracujeme pro organizaci, která pripravuje programy ekologické výchovy. Rádi bychom, aby to co děláme, dobře fungovalo. K tomu pripravujeme výzkum, se kterým od Tebe potřebujeme pomoct. Projdi si prosím následujicí dotazník a vyplň ho tak, jak si myslǐs, že to je pravda. Nikam se nepodepisuj, jenom Tě prosíme, abys na každou otázku odpovídal/-a nejlíp, jak můžeš. Vyplň prosím všechny otázky.

Díky za spolupráci, Honza (Technická univerzita v Liberci), Veronika (Středisko ekologické výchovy Český Ráj) a Bruce (Universita $v$ Arizoně)

\begin{tabular}{|c|c|c|c|c|c|c|}
\hline & & $\begin{array}{l}\text { Souhla- } \\
\text { sím }\end{array}$ & $\begin{array}{l}\text { Spíše } \\
\text { souhla- } \\
\text { sím }\end{array}$ & Nevím & $\begin{array}{l}\text { Spíše } \\
\text { nesou- } \\
\text { hlasím }\end{array}$ & $\begin{array}{l}\text { Nesou- } \\
\text { hlasím }\end{array}$ \\
\hline 1. & $\begin{array}{l}\text { Kdybych měl/-a nějaké peníze } \\
\text { navíc, dal/-a bych je na ochranu } \\
\text { prírody. }\end{array}$ & 0 & 0 & 0 & 0 & 0 \\
\hline 2. & $\begin{array}{l}\text { Abych v zimě ušetřil/-a energii, } \\
\text { zkontroluji, jestli topení } v \text { mém } \\
\text { pokoji netopí zbytečně moc. }\end{array}$ & 0 & 0 & 0 & 0 & 0 \\
\hline 3. & $\begin{array}{l}\text { Líbilo by se mi sedět na kraji } \\
\text { rybníka a pozorovat vážky. }\end{array}$ & 0 & 0 & 0 & 0 & 0 \\
\hline 4. & $\begin{array}{l}\text { Lidé maji právo měnit své životní } \\
\text { prostředí (přírodu) ve svůj } \\
\text { prospěch. }\end{array}$ & 0 & 0 & 0 & 0 & 0 \\
\hline 5. & $\begin{array}{l}\text { Stavět nové silnice je tak důležité, } \\
\text { že by se kvưli nim měly kácet } \\
\text { stromy. }\end{array}$ & 0 & 0 & 0 & 0 & 0 \\
\hline 6. & $\begin{array}{l}\text { Pomáhal/-a bych sehnat peníze } \\
\text { na ochranu prírody. }\end{array}$ & 0 & 0 & 0 & 0 & 0 \\
\hline 7. & $\begin{array}{l}\text { Vždy zhasnu světlo, když už } \\
\text { nepotřebuji svítit. }\end{array}$ & 0 & 0 & 0 & 0 & 0 \\
\hline
\end{tabular}




\begin{tabular}{|c|c|c|c|c|c|c|}
\hline 8. & $\begin{array}{l}\text { Rád/-a chodím na výlety ven } \\
\text { z města, třeba do lesa. }\end{array}$ & $\mathrm{O}$ & 0 & 0 & 0 & $\mathrm{O}$ \\
\hline 9. & $\begin{array}{l}\text { Mám radši udržovaný trávník než } \\
\text { louku, kde roste tráva divoce. }\end{array}$ & $\mathrm{O}$ & $\mathrm{O}$ & $\mathrm{O}$ & $\mathrm{O}$ & $\mathrm{O}$ \\
\hline 10. & $\begin{array}{l}\text { Protože komáři žiji } v \text { bažinách, } \\
\text { měly by se bažiny vysušit a jejich } \\
\text { půda využívat pro zemědělství. }\end{array}$ & $\mathrm{O}$ & $\mathrm{O}$ & $\mathrm{O}$ & $\mathrm{O}$ & 0 \\
\hline 11. & $\begin{array}{l}\text { Snažím se říkat ostatním, že } \\
\text { příroda je důležitá. }\end{array}$ & $\mathrm{O}$ & $\mathrm{O}$ & 0 & $\mathrm{O}$ & $\mathrm{O}$ \\
\hline 12. & $\begin{array}{l}\text { Snažím se šetřit vodou tak, že se } \\
\text { sprchuji krátkou dobu nebo } \\
\text { vypínám kohoutek při mytí zubů. }\end{array}$ & 0 & 0 & 0 & 0 & 0 \\
\hline 13. & Mám rád/-a klid a ticho přírody. & $\mathrm{O}$ & $\mathrm{O}$ & $\mathrm{O}$ & $\mathrm{O}$ & $\mathrm{O}$ \\
\hline 14. & $\begin{array}{l}\text { Aby měli lidé dost jídla, musí se } \\
\text { divoká příroda přeměnit na pole. }\end{array}$ & $\mathrm{O}$ & 0 & $\mathrm{O}$ & $\mathrm{O}$ & $\mathrm{O}$ \\
\hline 15. & Lidé mají vládnout přírodě. & $\mathrm{O}$ & $\mathrm{O}$ & $\mathrm{O}$ & $\mathrm{O}$ & $\mathrm{O}$ \\
\hline 16. & $\begin{array}{l}\text { Plevel by se měl vyhubit, protože } \\
\text { zabírá místo rostlinám, které } \\
\text { potřebujeme. }\end{array}$ & 0 & 0 & 0 & 0 & 0 \\
\hline
\end{tabular}


PŘÍLOHA Č. 2 DOTAZNÍK PRO MLADÉHO BADATELÉ MĚŘíCÍ SPOKOJENOST ÚČASTNÍKA A PŘÍNOSY PROGRAMU

Dotazník pro mladého badatele

Prosíme Tě o pár rychlých odpovědí ke dnešní badatelské hodině. Díky za pomoc! Honza.

V dotazníku se ptáme vždy na něco, co má dvě krajní možnosti. Napřiklad dneska ti ve třídě mohlo být spíš teplo, nebo zima. Vyplňuj tak, že čím víc budeš souhlasit s některou z nich, tím bližší smajlík vyber. Otazník uprostřed znamená, že se nedokážeš rozhodnout ani pro jednoho z nich. Podívej se na př́klad:

\begin{tabular}{|c|c|c|c|c|c|c|c|}
\hline Dneska ve třídě bylo & teplo & (-) & $?$ & (-) & (ن) & (-) & zima \\
\hline
\end{tabular}

Znamená to, že dneska mi bylo docela teplo, ale ne úplně nejvíc, co jsem kdy zažil. Nezapomeň, kroužkuj vždy smajlíka nebo otazník. Pokud Ti něco není jasné, zeptej se svého učitele. Díky!

\begin{tabular}{|c|c|c|c|c|c|c|c|c|c|}
\hline Dnešní hodina byla & nudná & ;) & ;) & ;:) & ? & (;) & ;:) & (:) & zábavná \\
\hline $\begin{array}{l}\text { Spolupráce se spolužáky } \\
\text { byla }\end{array}$ & prima & ;) & (;) & ;:) & ? & ;) & ;) & (;) & hrozná \\
\hline Naučil/-a jsem se toho & hodně & ;) & (;) & ;) & ? & ;) & ;) & ;) & nic \\
\hline Bylo to pro mě & těžké & ;) & (;) & ;) & ? & (;) & (:) & (;) & snadné \\
\hline
\end{tabular}

Doplň prosím následující věty, které se týkají toho, co jsi se dneska naučil/-a:

Před dnešní hodinou jsem nevěděl/-a, že

Před dnešní hodinou jsem ještě neuměl/-a

Nejvíc mě překvapilo, 
Vyšlo s podporou projektu TAČR „Hodnocení efektivity nástrojů environmentálního vzdělávání, výchovy a osvěty (EVVO)“. Vydal a technická úprava BEZK a Agentura Koniklec, Praha, 2013.

Recenzovali: Mgr. Petr Daniš (Sdružení TEREZA), Mgr. et Mgr. Michal Medek (Středisko ekologické výchovy Kaprálův mlýn). 